\title{
LOCALIZATION OF NUCLEOLAR CHROMATIN BY IMMUNOCYTOCHEMISTRY AND IN SITU HYBRIDIZATION AT THE ELECTRON MICROSCOPIC LEVEL
}

\author{
MARC THIRY,* ULRICH SCHEER $\dagger$ and GUY GOESSENS* \\ *Laboratory of Cell and Tissue Biology, University of Liège, rue de Pitteurs, 20, B-4020 Liège, Belgium \\ $\dagger$ Institute of Zoology I, University of Würzburg, Röntgenring 10, D-8700 Würzburg, F.R.G.
}

\begin{abstract}
Nucleoli are the morphological expression of the activity of a defined set of chromosomal segments bearing rRNA genes. The topological distribution and composition of the intranucleolar chromatin as well as the definition of nucleolar structures in which enzymes of the rDNA transcription machinery reside have been investigated in mammalian cells by various immunogold labelling approaches at the ultrastructural level. The precise intranucleolar location of rRNA genes has been further specified by electron microscopic in situ hybridization with a non-autoradiographic procedure.

Our results indicate that the fibrillar centers are the sole nucleolar structures where rDNA, core histones, RNA polymerase I and DNA topoisomerase I are located together.

Taking into account the potential value and limitations of immunoelectron microscopic techniques, we propose that transcription of the rRNA genes takes place within the confines of the fibrillar centers, probably close to the boundary regions to the surrounding dense fibrillar component.
\end{abstract}

\section{CONTENTS}

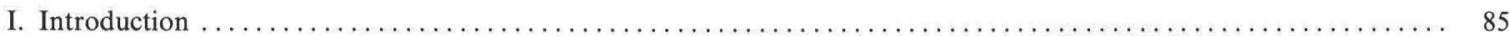

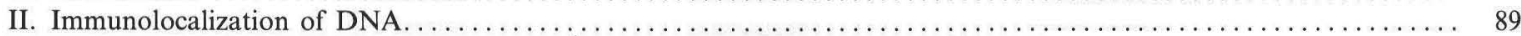

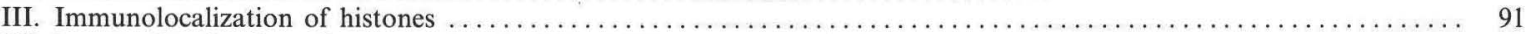

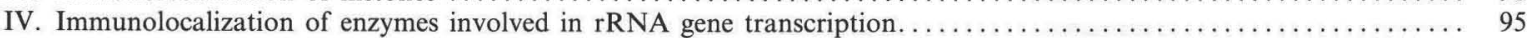

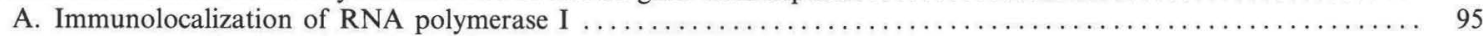

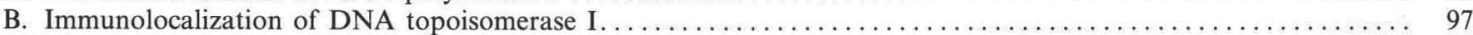

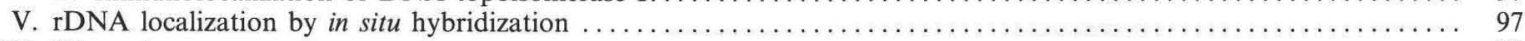

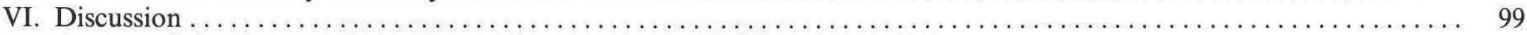

A. Potential value and limitations of immunoelectron microscopic techniques $\ldots \ldots \ldots \ldots \ldots \ldots \ldots \ldots \ldots \ldots \ldots, 101$

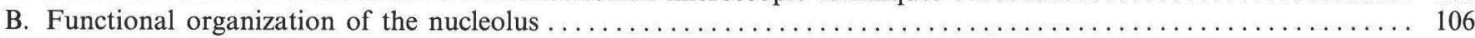

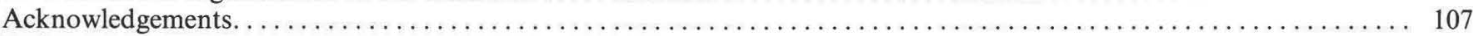

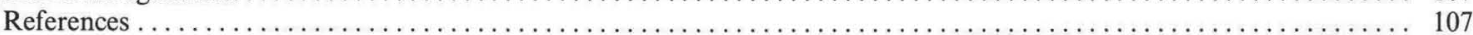

\section{INTRODUCTION}

The nucleolus is the result of the activity of a defined set of chromosomal segments bearing rRNA genes. Extensive ultrastructural studies have provided profound knowledge concerning the ultrastructural composition of the nucleolus. Accordingly, fibrillar centers, dense fibrillar component, granular component, interstices or "vacuoles" and nucleolus-associated chromatin are commonly recognized as the general components of interphasic nucleoli (Fig. 1; review in
Smetana and Busch, 1974; Jordan and Cullis, 1982; Goessens, 1984). Autoradiographic techniques in combination with biochemical methods have allowed one to assign to the dense fibrillar component the primary steps of preribosome formation whereas subsequent maturation processes occur in the granular component (reviewed by Fakan, 1978; Hadjiolov, 1985). However, the precise relationships between these structural components and their molecular functions remain unresolved. In particular, the spatial distribution of the transcribing rRNA genes within the nucleolar 


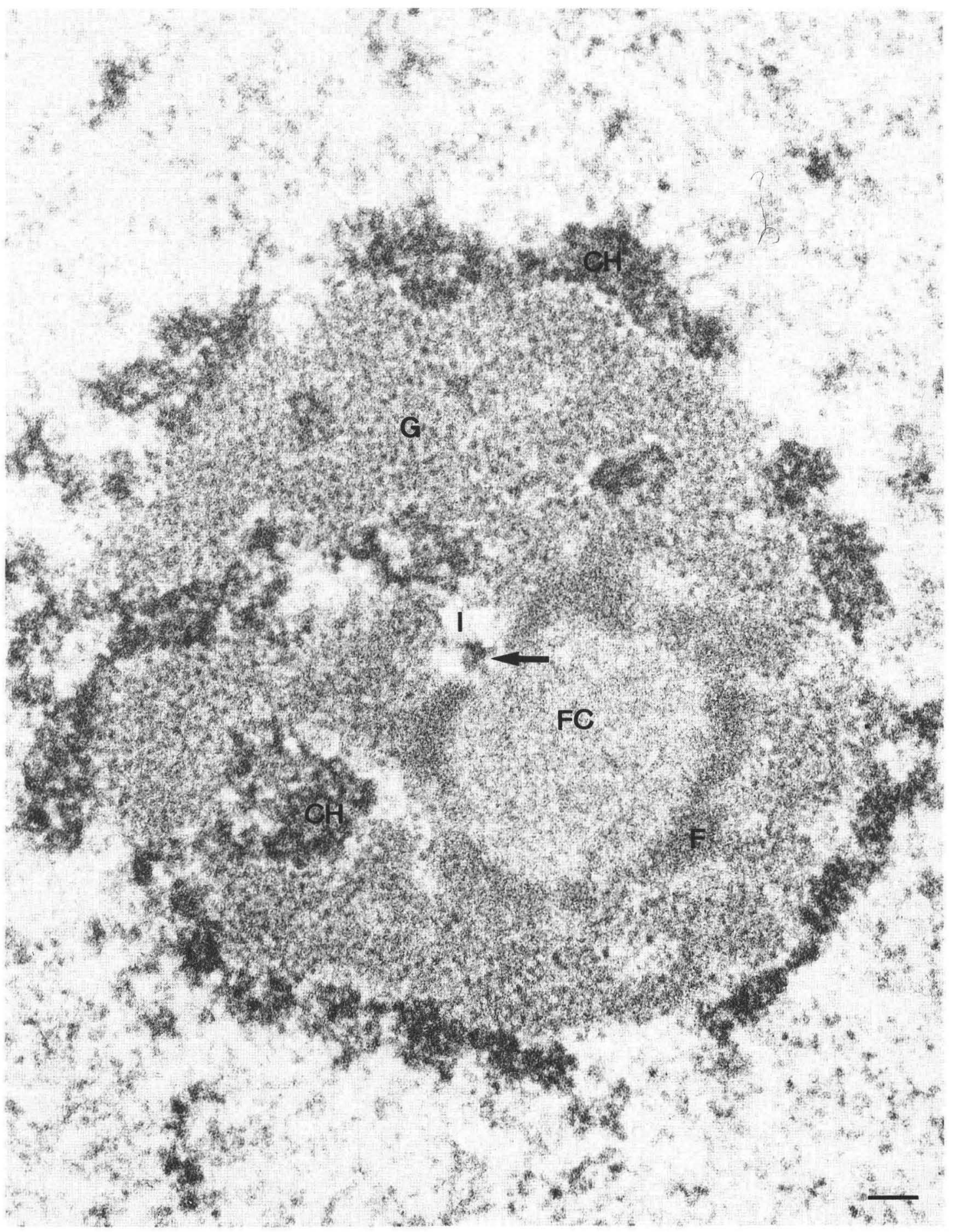

Fig. 1. Ultrastructure of a HEp-2 cell nucleolus. Fibrillar center (FC) is surrounded by a layer of dense fibrillar component (F) interrupted by nucleolar interstices (I) in which condensed chromatin (arrow) approaches the fibrillar center. The nucleolus-associated chromatin $(\mathrm{CH})$, situated at peri- and intranucleolar positions, is heavily stained by the acetylation method (for details see Thiry et al., 1985). Granular component (G). Scale marker indicates $0.1 \mu \mathrm{m}$. 
body is still a matter of debate (compare, e.g., the results and conceptions presented by Scheer and Rose, 1984, and Wachtler et al., 1989).

In order to understand the functional organization of the nucleolus, it is of fundamental importance to know where exactly the active rRNA genes or transcription units are located. Although transcriptionally active rRNA genes can be visualized by the chromatin spreading technique introduced by O. Miller (Miller and Beatty, 1969; Fig. 2a), this approach does not provide an answer as to their intranucleolar localization. Nucleoli disintegrate during the low salt treatment necessary to unravel chromatin and it is thus impossible to relate the transcription units to a specific nucleolar component. However, visualization of transcribing rRNA genes at the molecular level has contributed substantially to the present knowledge of rRNA gene arrangement and chromatin structure (for reviews see Miller, 1981; Trendelenburg, 1983; Hadjiolov, 1985; Scheer, 1987). In addition, this technique clearly demonstrates that numerous rRNA transcription units must be considerably condensed and foreshortened in the intact nucleolus (compare Figs $2 \mathrm{a}$ and $2 \mathrm{~b}$; both are magnified to the same scale). Thus, even a single mouse rRNA transcription unit with an axial length of approximately $4 \mu \mathrm{m}$ (Fig. $2 \mathrm{a}$ ) reaches the diameter of a nucleolus in situ (Fig. 2b) and it is well known that some hundred transcription units reside in a nucleolus (for quantitative data see Hadjiolov, 1985).

There have been numerous attempts to elucidate the location of nucleolar chromatin in situ at the electron microscopic level by employing a variety of methods such as enzymatic digestions, preferential or selective staining, autoradiography after incorporation of tritiated thymidine or tritiated actinomycin D and labelling with DNase-gold complexes. These different methods have provided clear evidence that the perinucleolar condensed chromatin penetrates at several places deep into the nucleolar body (see Fig. 1). However, the limited resolution and/or lack of specificity of these procedures did not allow one to describe precisely the spatial distribution of the decondensed rDNAcontaining chromatin within the nucleolus and to identify unequivocally one of the fibrillar components (fibrillar center or dense fibrillar component) as the site of transcription.
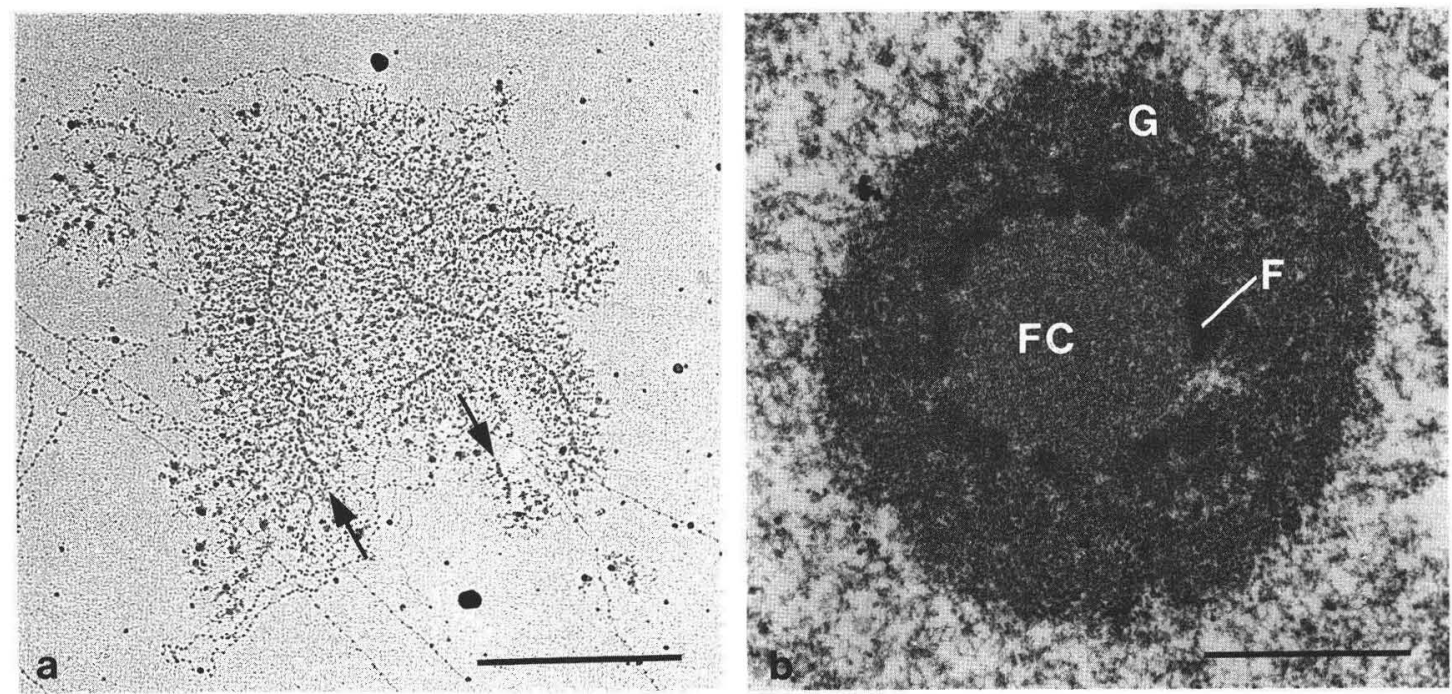

Fig. 2. Electron micrographs showing, at the same magnification, spread nucleolar chromatin from a mouse fibroblast (a) and a nucleolus of a mouse Ehrlich ascites tumor cell fixed in situ (b). The rRNA transcription unit shown (its initial and terminal regions are indicated by arrows) has an axial length of approximately $4 \mu \mathrm{m}$ (a). Based on purely morphological criteria it is impossible to identify them in sectioned nucleoli (b). Note the large fibrillar center (FC), the surrounding dense fibrillar component (F) and the granular component (G). Scale markers indicate $1 \mu \mathrm{m}$. 


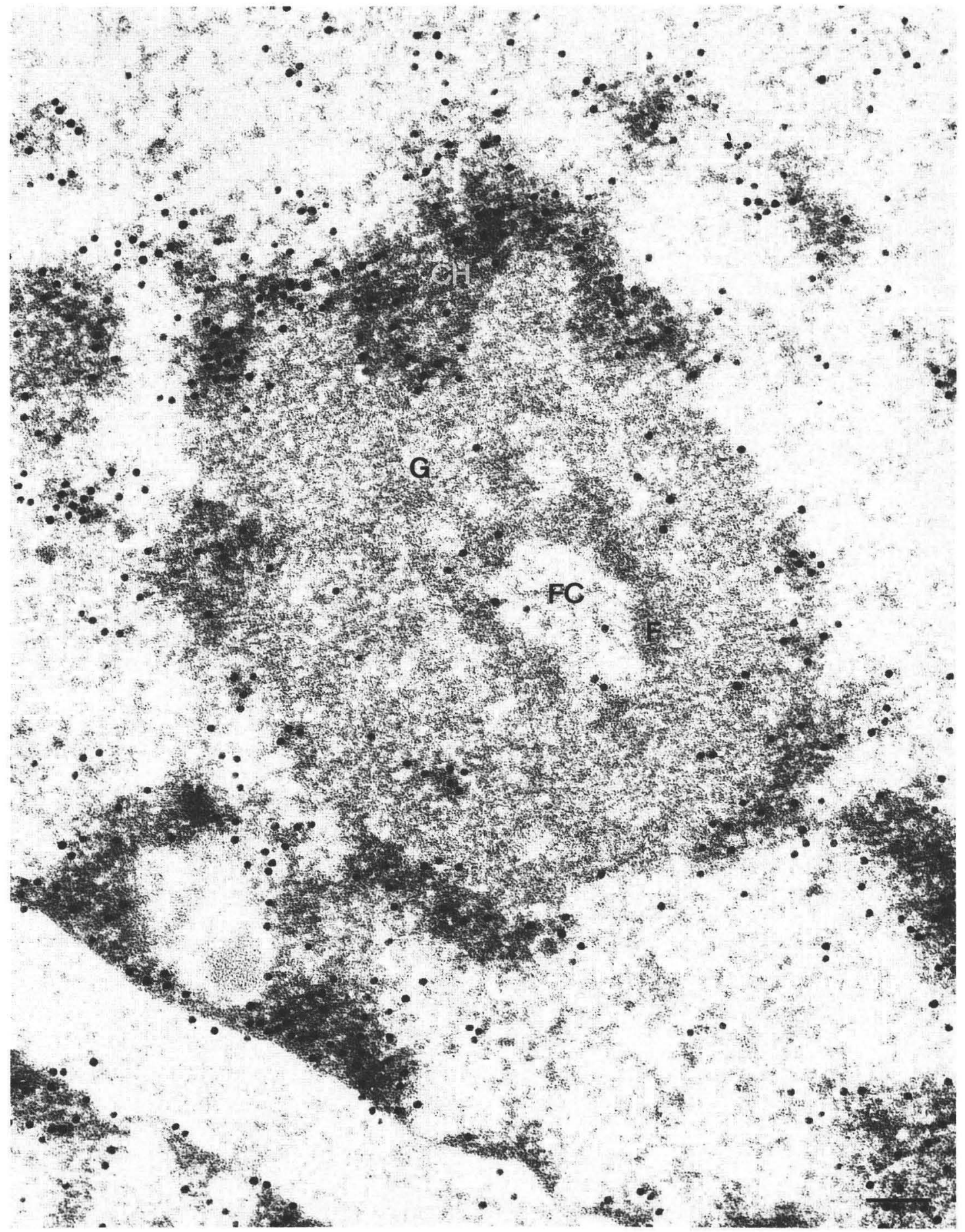

Fig. 3. Electron micrograph showing the labelling of an ultrathin Lowicryl section of cultured human HEp-2 cells with a serum from a patient suffering from SLE. Gold particles are particularly enriched over the perinucleolar and intranucleolar condensed chromatin $(\mathrm{CH})$. Fibrillar center $(\mathrm{FC})$, dense fibrillar component $(\mathrm{F})$, granular component $(\mathrm{G})$. Scale marker indicates $0.1 \mu \mathrm{m}$. 
Recently, several authors have used electron microscopic immunocytochemical methods to locate rDNA-containing intranucleolar chromatin. These techniques exploit the highly specific reaction between antigen and antibody by using labelled immune reagents to localize antigens in situ; consequently, both the specificity and the precision are the main advantages of these techniques. Furthermore, antibodies can be used at the electron microscopic level for detecting biotinylated DNA or RNA hybridization probes, offering the possibility to study precisely the location of specific nucleic acid sequences within the cell by in situ hybridization.

The main goal of the present review is to summarize, on the one hand, recent contributions of immunocytochemical approaches to elucidate the location and composition of the intranucleolar chromatin of mammalian nucleoli and, on the other hand, to define those structures in which enzymes of the rRNA transcription machinery reside. Another important purpose of this review is to specify the location of rRNA genes within nucleoli by means of in situ hybridization. These results will be discussed in the light of the present understanding of the functional organization of the nucleolus.

\section{IMMUNOLOCALIZATION OF DNA}

Several years ago, Raska et al. (1983) studied the in situ location of DNA by means of electron microscopic immunocytochemistry. This approach was based on the use of autoimmune antibodies reacting with double-stranded DNA. The labelled sites were then revealed with protein $\mathrm{A}$-gold complexes. The authors showed that the labelling was mainly confined to the condensed chromatin regions of both $\mathrm{HeLa}$ and $\mathrm{CHO}$ cell nuclei including the peri- and intranucleolar condensed chromatin clumps. Such anti-DNA antibodies used frequently occur in sera from patients suffering from systemic lupus erythematosus (SLE; for reviews see: Stollar, 1975, 1986; Tan, 1982; Tan et al., 1988). However, the application of SLE sera is limited because they usually contain a mixture of different antibodies with different specificities
(Arana and Seligmann, 1967; Notman et al., 1975; Gilliam et al., 1980) which might include antibodies directed against other nuclear components such as histones and small nuclear RNPs (for review see Tan et al., 1988). Thus, although DNArich structures such as the condensed chromatin are clearly labelled by these SLE sera (Fig. 3), the molecular interpretation of the labelling pattern remains, at least to some extent, ambiguous without affinity-purification of antibodies directed against DNA. In addition, the limited supply of patients antisera poses another problem.

In order to overcome these limitations, Scheer et al. (1987) raised a murine anti-DNA monoclonal antibody (AK30-10; this antibody is now commercially available from Boehringer, Mannheim, F.R.G.) with a defined antigenic specificity. This monoclonal antibody recognizes an epitope present on both single- and double-stranded DNA but absent from other molecules and structures, including nucleotides, histones and RNAs. However, when various synthetic double-stranded polynucleotides were tested by competitive ELISA, it became apparent that the antibody recognition was not exclusively based on a feature of the deoxyribose phosphate backbone of the DNA chain but was also influenced to some extent by the base composition. Immunofluorescence microscopy on permeabilized cultured cells revealed a strong fluorescence of nuclei and mitotic chromosomes (Fig. 4). Even minor amounts of DNA present in structures such as amplified extrachromosomal nucleoli, chromomeres of lampbrush chromosomes, mitochondria, chloroplasts and mycoplasmal particles have been clearly identified (Scheer et al., 1987). When Lowicryl ultrathin sections of rat liver tissue were incubated with the anti-DNA antibody followed by secondary antibodies coupled to colloidal gold, gold particles were enriched over the condensed chromatin of the nuclear periphery and the perinucleolar region. The nucleolus usually appeared as a zone of exclusion of gold particles except for some small intranucleolar regions which could represent invaginations of the surrounding nucleolusassociated heterochromatin (Scheer et al., 1987). However, following a preembedding immunogold labelling protocol, gold particles were also clearly 

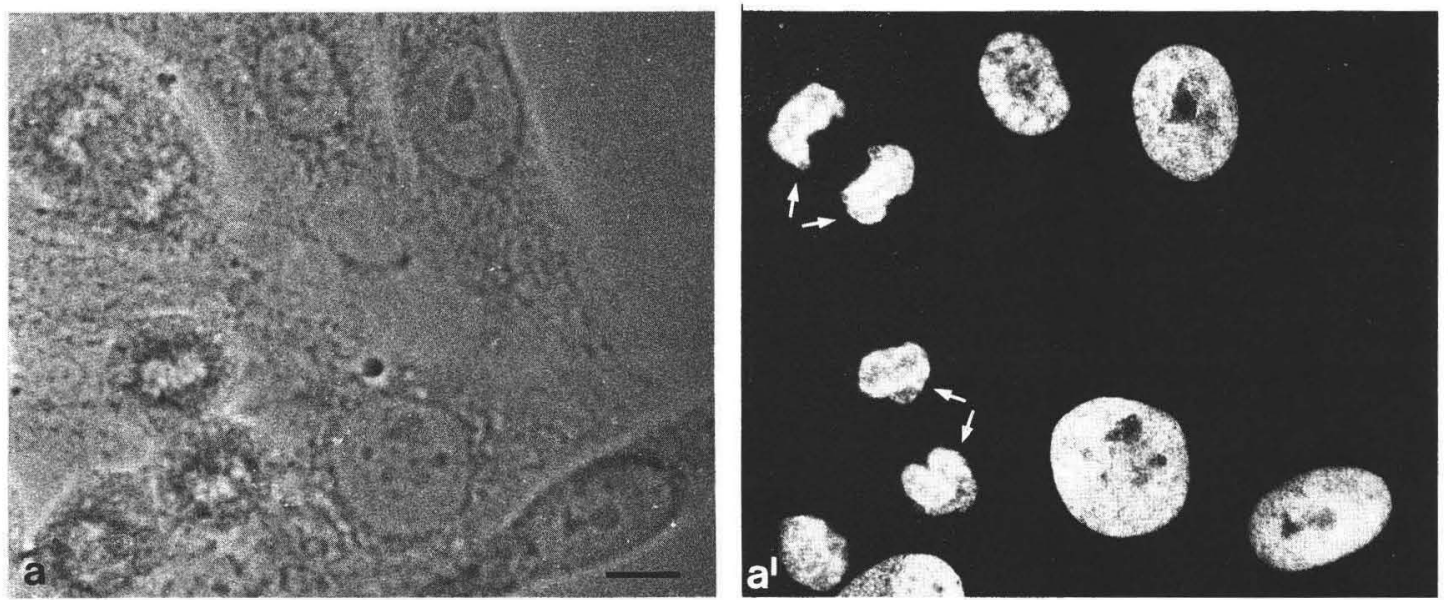

Fig. 4. Immunofluorescence microscopy of cultured rat cells after reaction with the monoclonal anti-DNA antibody AK30 $\left(a^{\prime}\right)$. Note the strong reaction with mitotic chromosomes (arrows). The corresponding phase contrast is shown in (a). Scale marker indicates $10 \mu \mathrm{m}$.

visualized in the fibrillar centers of hepatocyte cell nucleoli. An example is presented in Fig. 5. Gold particles selectively decorate a network of fine filaments present in the fibrillar centers but are absent from the surrounding dense fibrillar component.

Using the same monoclonal anti-DNA antibody, Thiry et al. (1988) confirmed and extended

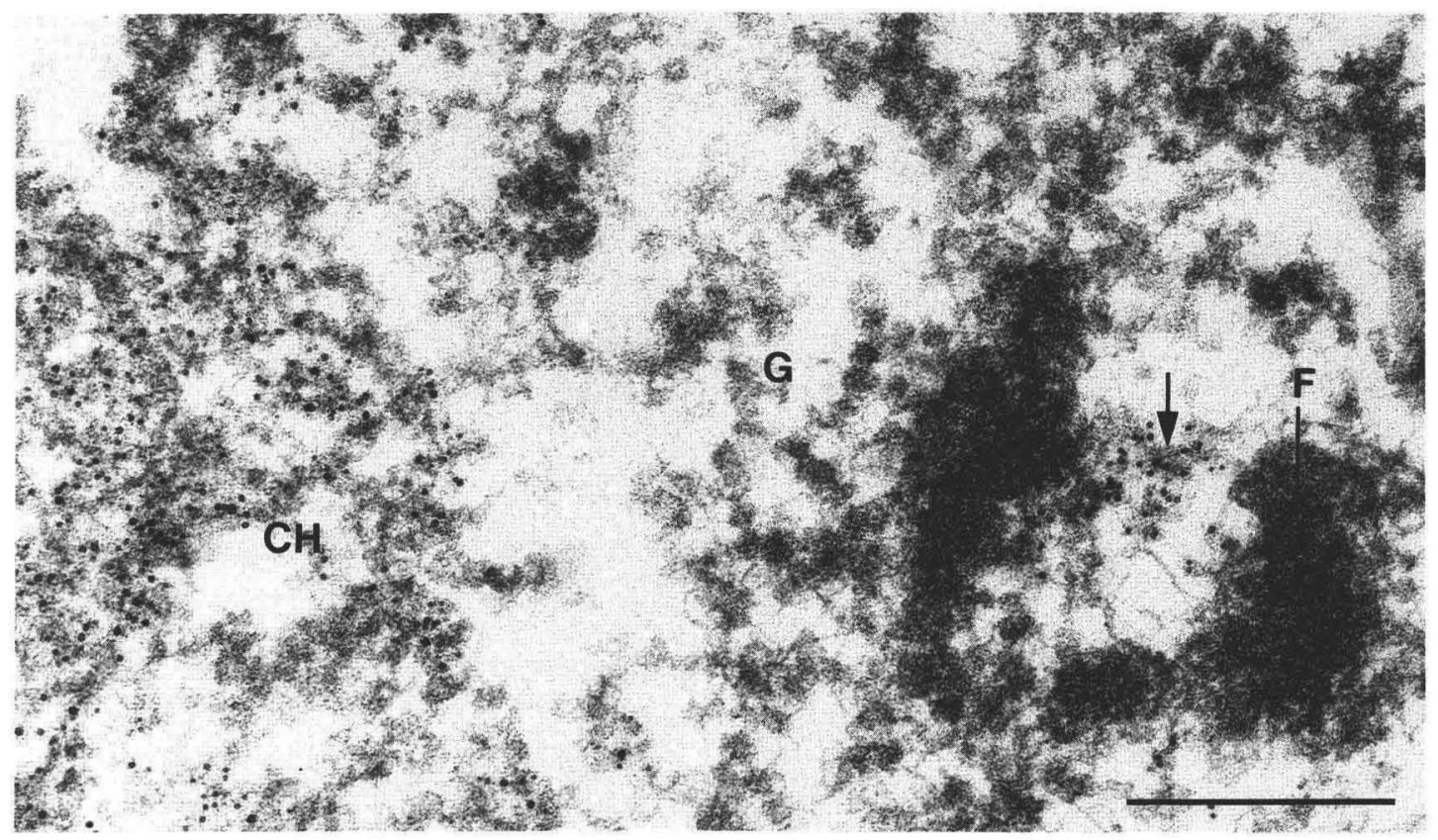

Fig. 5. Electron microscopic immunolocalization of DNA using a preembedding protocol. A frozen section ( $5 \mu \mathrm{m})$ of rat liver was incubated with monoclonal antibodies against DNA followed by secondary antibodies coupled to $5 \mathrm{~nm}$ gold particles and processed for electron microscopy (for details see Scheer et al., 1987). Gold particles decorate the fine filaments of the fibrillar center (arrow) but are absent from the dense fibrillar component (F) and the granular component (G) of the nucleolus. The perinucleolar chromatin $(\mathrm{CH})$ is heavily labelled with gold. Scale marker indicates $1 \mu \mathrm{m}$. 
these results by following a postembedding procedure with Ehrlich tumour cells (Fig. 6). These cells contain nucleoli with large fibrillar centers ensheathed by a thin layer of dense fibrillar component (Figs 1 and 2b). This favorable cytological situation, in conjunction with the Lowicryl postembedding procedure, allows one to obtain an excellent distinction between the various nucleolar components contrary to the preembedding protocol. Under these experimental conditions, gold labelling is particularly concentrated at the perinucleolar chromatin shell and its intranucleolar invaginations which are sometimes in contact with the fibrillar center (Fig. 6; Thiry et al., 1988). At this place, the layer of the dense fibrillar component surrounding the fibrillar center is interrupted by small interstices usually containing small clumps of chromatin (see Fig. 1). In addition, a small but significant number of gold particles is consistently present in the fibrillar centers, preferentially towards their peripheral regions (Fig. 6). In contrast, the dense fibrillar component is completely devoid of gold particles (Fig. 6; see also Thiry et al., 1988).

Concomitantly with the immunocytochemical approach involving the monoclonal anti-DNA antibody, Thiry and Dombrowicz (1988) adapted a new technology allowing the visualization of newly replicated DNA in situ at the electron microscopic level. DNA in which bromodeoxyuridine (BUdR) had been previously incorporated was detected on ultrathin sections by means of a monoclonal antibody specifically directed against BUdR (Gratzner, 1982) followed by secondary antibodies coupled to colloidal gold. In order to obtain a labelling pattern reflecting the general distribution of DNA, i.e. including early and late replicating DNA domains, Ehrlich tumour cells were exposed to BUdR for one cell cycle (21 hr; Lepoint, 1977). Biological material embedded in Lowicryl K4M was initially used for immunodetection (Thiry and Dombrowicz, 1988) but positive results were also obtained with other resins such as Epon and LR White and with ultrathin cryosections. Independent of the specific procedure used, the detection of BUdR incorporated into DNA requires prior denaturation of the DNA to render the epitopes accessible to the antibodies as already noticed at the light microscope level (Moran et al. 1985). Under these conditions, the pattern of gold labelling of the nucleolus (Fig. 7) is identical to that obtained with the monoclonal anti-DNA antibody (Thiry, 1988). Besides an intense labelling over the perinucleolar heterochromatin shell and its intranucleolar invaginations, small clusters of gold particles are preferentially distributed towards the peripheral regions of the fibrillar centers, often in close proximity to nucleolar interstices interrupting the surrounding layer of dense fibrils. The dense fibrillar component and the granular component always appear free of labelling with the exception of the nucleolar interstices containing condensed chromatin (Fig. 7). The labelling of the fibrillar centers is particularly clearly seen after trypsin extraction (Fig. 8). When this immunocytochemical technique was applied on HEp-2 cells, identical results were obtained (Thiry, 1989).

\section{IMMUNOLOCALIZATION OF HISTONES}

A considerable amount of data indicate that most eukaryotic DNA is packaged in a fundamental unit, the nucleosome core particle (for reviews see: Kornberg, 1977; McGhee and Felsenfeld, 1980). However, it has become apparent that this nucleosomal subunit of chromatin is not a static entity but undergoes changes as a function of transcription. Moreover, it is generally assumed that the nucleosomal packaging of active genes differs from that of the bulk chromatin (for reviews see: Reeves, 1984; Van Holde, 1989). In the case of extremely active genes such as the rRNA genes typical nucleosomes are lacking indicating that they either occur in a stably unfolded conformation or histones are displaced from the rDNA (see Van Holde, 1989).

When Lowicryl ultrathin sections of Ehrlich ascites cells were incubated with antibodies to various core histones (H2B, H3, H4) including antibodies directed against the $\mathrm{N}$-terminal region of histone $\mathrm{H} 2 \mathrm{~B}$ and the $\mathrm{C}$-terminal region of histone H3 known to remain exposed after nucleosome formation, nuclear chromatin was specifically decorated (Thiry and Muller, 1989). Gold labelling 


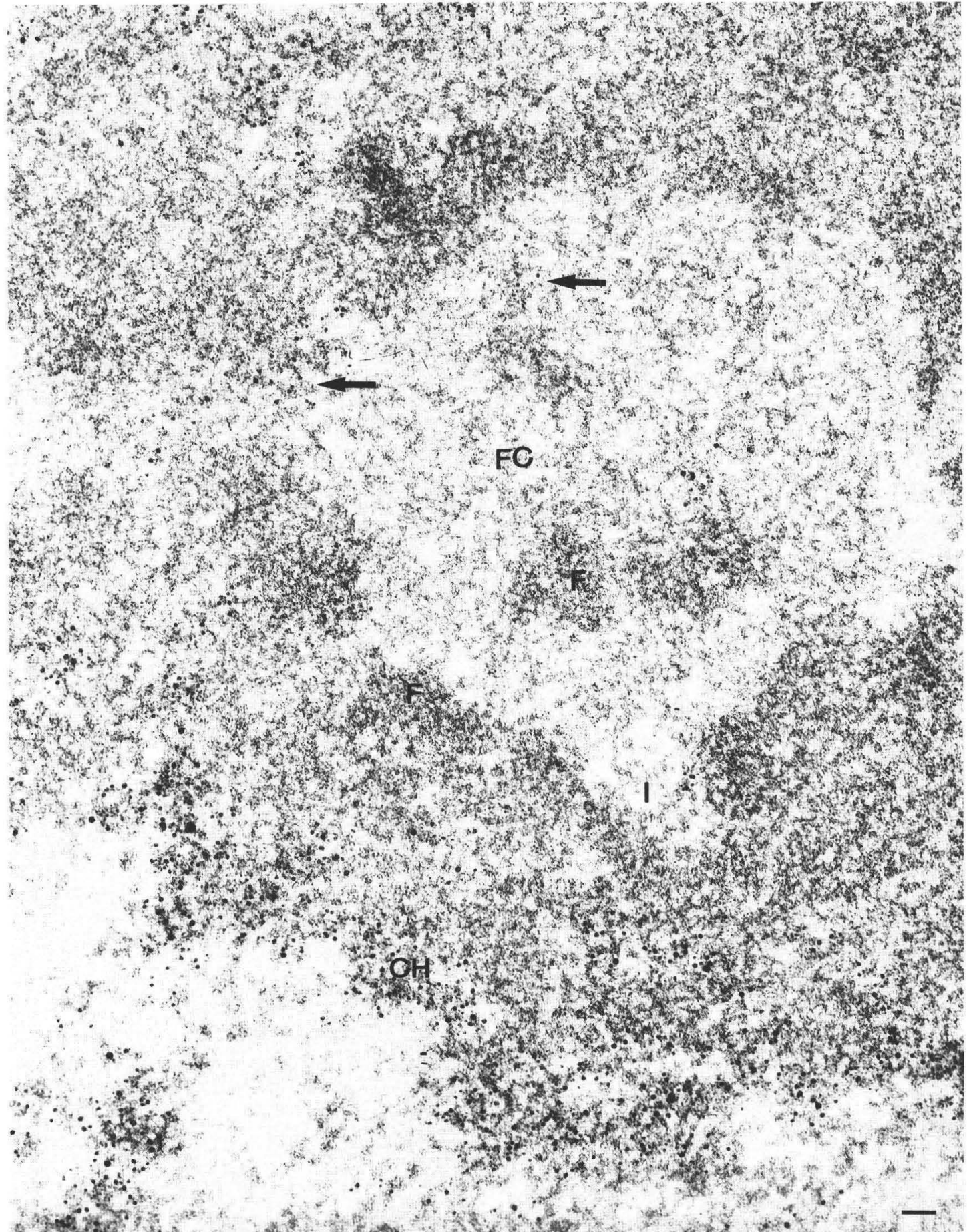

Fig. 6. Electron microscopic immunolocalization of DNA on sections of Lowicryl-embedded Ehrlich tumor cells. Gold particles decorate the perinucleolar chromatin and its intranucleolar invaginations $(\mathrm{CH})$. The latter come into contact with the fibrillar center (FC) and are situated in interstices (I). Gold particles are present in the fibrillar center preferentially towards its peripheral regions (arrows). The dense fibrillar component (F) is almost completely unmarked; however, gold particles are present at its periphery, even when the dense fibrils are located inside the fibrillar center. Scale marker indicates 


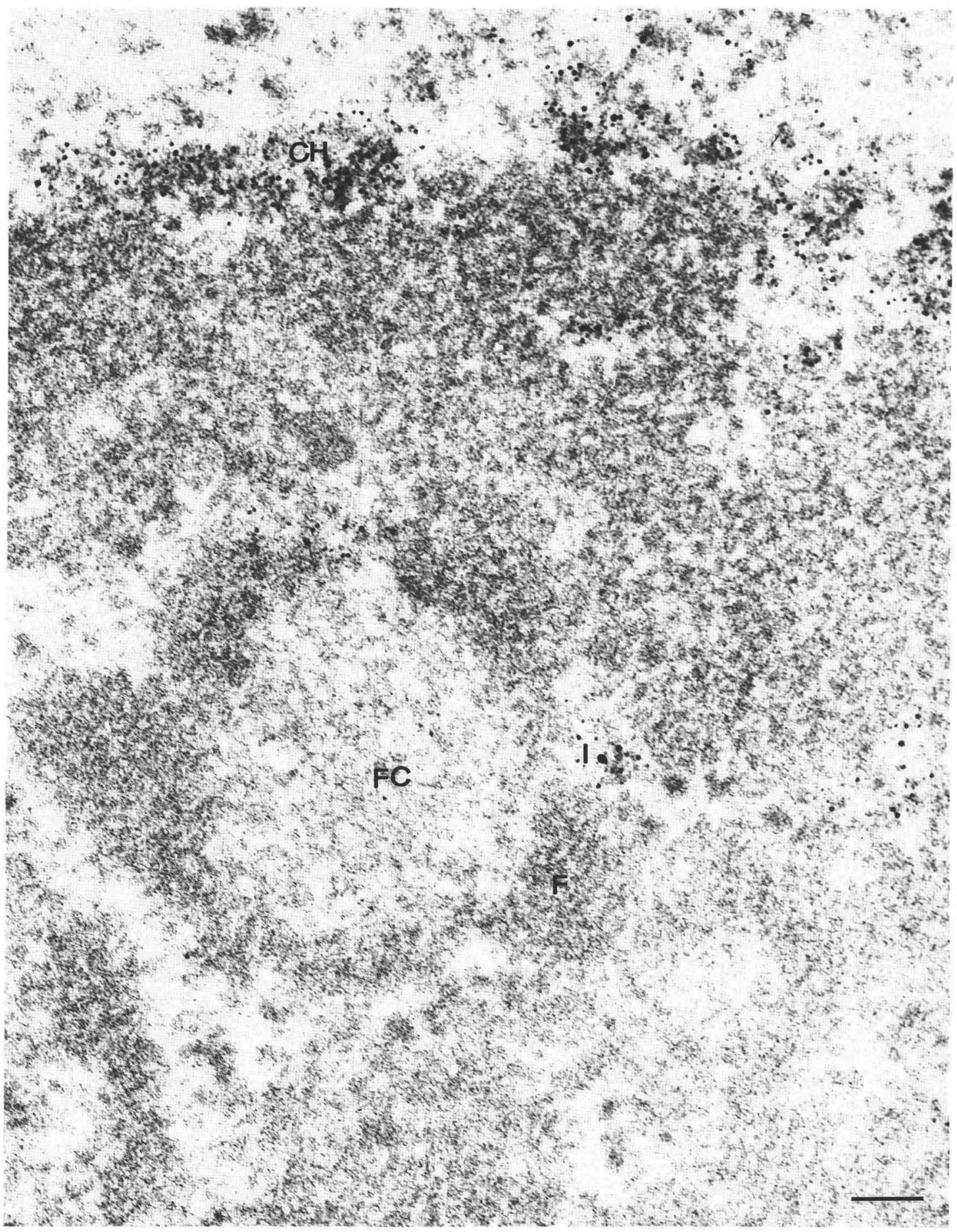

Fig. 7. Electron microscopic immunolocalization of BUdR incorporated into DNA on sections of Lowicryl-embedded Ehrlich tumor cells. The pattern of gold labelling of the nucleolus is identical to that obtained with anti-DNA antibody (compare with Fig. 6). Fibrillar center (FC), dense fibrillar component (F), interstices (I) and associated chromatin (CH). Scale marker indicates $0.1 \mu \mathrm{m}$. 


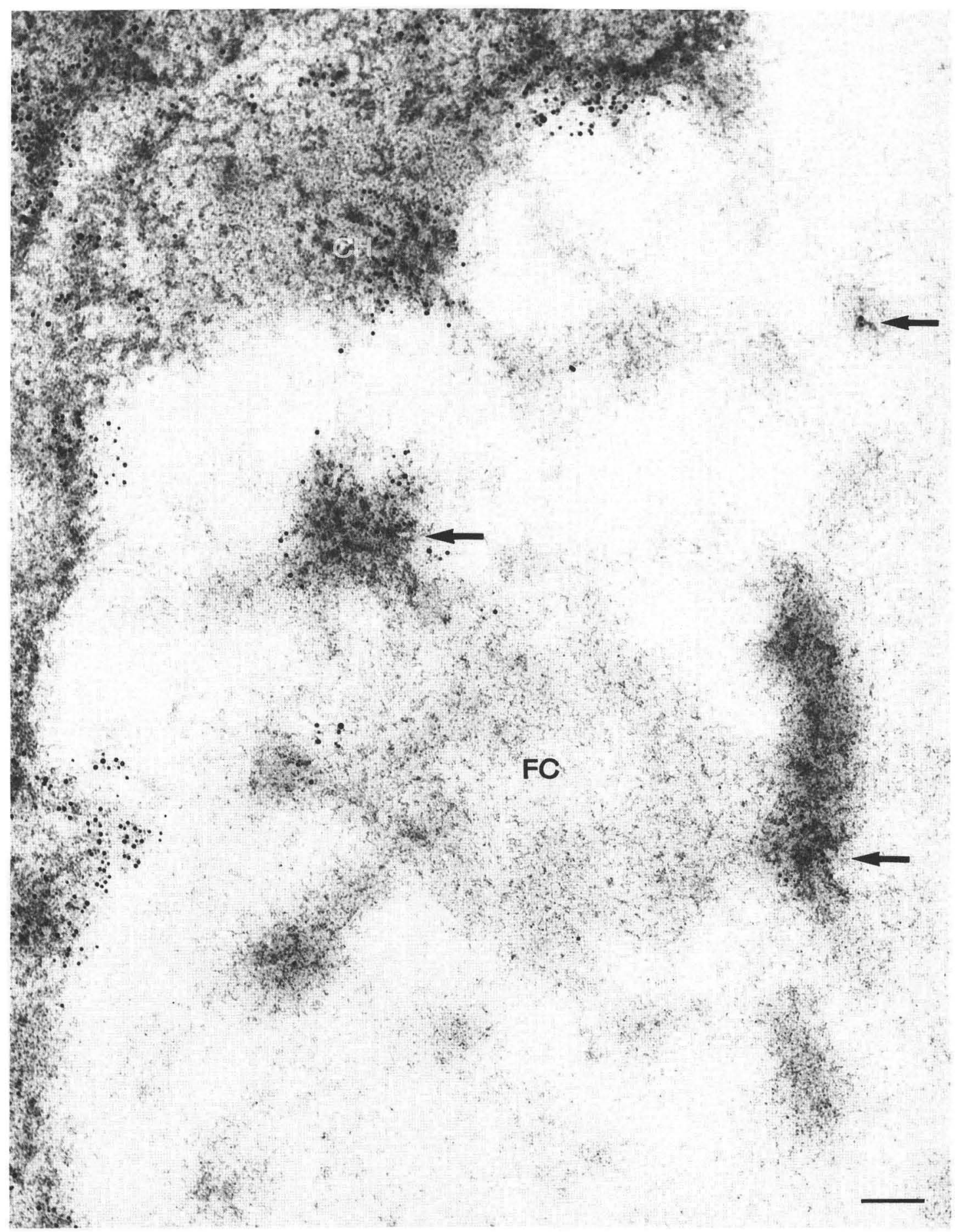

Fig. 8. Electron microscopic immunolocalization of BUdR incorporated into DNA on sections of Lowicryl-embedded Ehrlich tumor cells after a prior trypsin treatment. Gold particles are essentially localized over the perinucleolar chromatin $(\mathrm{CH})$ and over their intranucleolar invaginations (arrows). In addition, a few gold particles are preferentially found at the periphery of the fibrillar center (FC). Scale marker indicates $0.1 \mu \mathrm{m}$. 
of nucleoli was found over the perinucleolar heterochromatin and its intranucleolar invaginations which penetrate the nucleolar body and come in close contact with the fibrillar centers. In addition, a few gold particles were consistently noted in the fibrillar centers, preferentially located towards their peripheral regions (Fig. 9). To compare the spatial distribution of DNA and histones on the same section, a double labelling protocol has been devised (Thiry and Muller, 1989). For the localization of DNA, ultrathin sections are floated on a droplet containing the monclonal anti-DNA antibody followed by secondary antibodies coupled to $10 \mathrm{~nm}$ gold particles. Once the first labelling is performed, the sections are mounted on collodion-coated gold grids and the second face is then labelled using antisera raised against purified histones followed by the appropriate secondary antibodies coupled to $5 \mathrm{~nm}$ gold particles. In this way, the immunolabelling of each face of the sections is independently performed, hence avoiding steric hindrance of the antibodies. Using this approach, histones and DNA can be colocalized inside the fibrillar centers (Fig. 9) indicating that the fibrillar center DNA is complexed with histones. While these in situ observations agree with the view that histones remain bound to the rRNA genes even when they are heavily transcribed (e.g. Reeder et al., 1978; Zayets et al., 1981; Prior et al., 1983; Johnson et al., 1987), they do not pertain to the question as to whether or not nucleolar chromatin is organized into nucleosomes.

\section{IMMUNOLOCALIZATION OF ENZYMES INVOLVED IN rRNA GENE TRANSCRIPTION}

\section{A. Immunolocalization of RNA Polymerase I}

Although immunodetection of DNA and histones is a valuable approach to analyze the topological distribution and composition of intranucleolar DNA, it remains open whether the structures identified do indeed contain transcriptionally active rRNA genes and not, for example, inactive rDNA stretches or spacer regions interspersed between adjacent rRNA transcription units. To approach this question, antibodies against the key enzyme involved in transcription of the rRNA genes, RNA polymerase I, have been used for immunolocalization (Scheer and Rose, 1984). Active rRNA genes are usually covered by densely spaced transcribing RNA polymerase I molecules from which transcript fibrils extend laterally (Fig. 2a). The lateral fibrils containing the nascent pre-rRNA chains gradually increase in length in the direction of transcription giving rise to the characteristic 'Christmas tree' aspect (for molecular interpretation of spread preparations of nucleolar chromatin see, e.g., Miller, 1981; Scheer, 1987). Individual RNA polymerase I molecules can be identified as distinct particles anchoring the lateral transcript fibrils to the chromatin axis (Fig. 2a). Since the class I RNA polymerase is exclusively involved in transcription of the rRNA genes (for review see Rose et al., 1983), the distribution of this enzyme should accurately reflect the sites where the transcription units are located.

The antibodies used were raised in rabbits against purified RNA polymerase I from rat Morris hepatoma (Rose et al., 1981) or were obtained from sera of patients suffering from scleroderma autoimmune disease (Reimer et al., 1987a,b). Immunofluorescence microscopy clearly reveals that these antibodies specifically and intensely react with the nucleoli of mammalian cells such as cultured rat cells (Fig. 10a'). The striking punctate pattern of the nucleolar fluorescence indicates that the RNA polymerase I molecules occur in several discrete subnucleolar components. In this context, it should be mentioned that nucleoli of the specific cell type shown contain several small fibrillar centers distributed throughout the nucleolar body (see also Ochs and Smetana, 1989).

In order to identify the nucleolar components reacting with antibodies to RNA polymerase I in greater detail, we employed both pre- and postembedding electron microscopic immunolabelling procedures. The preembedding technique (see Scheer and Rose, 1984) has the advantage that the immunoreactions can be performed on frozen rat liver sections without any prior chemical fixation, similar to the light microscopic immunofluorescence protocol. An example is presented in 


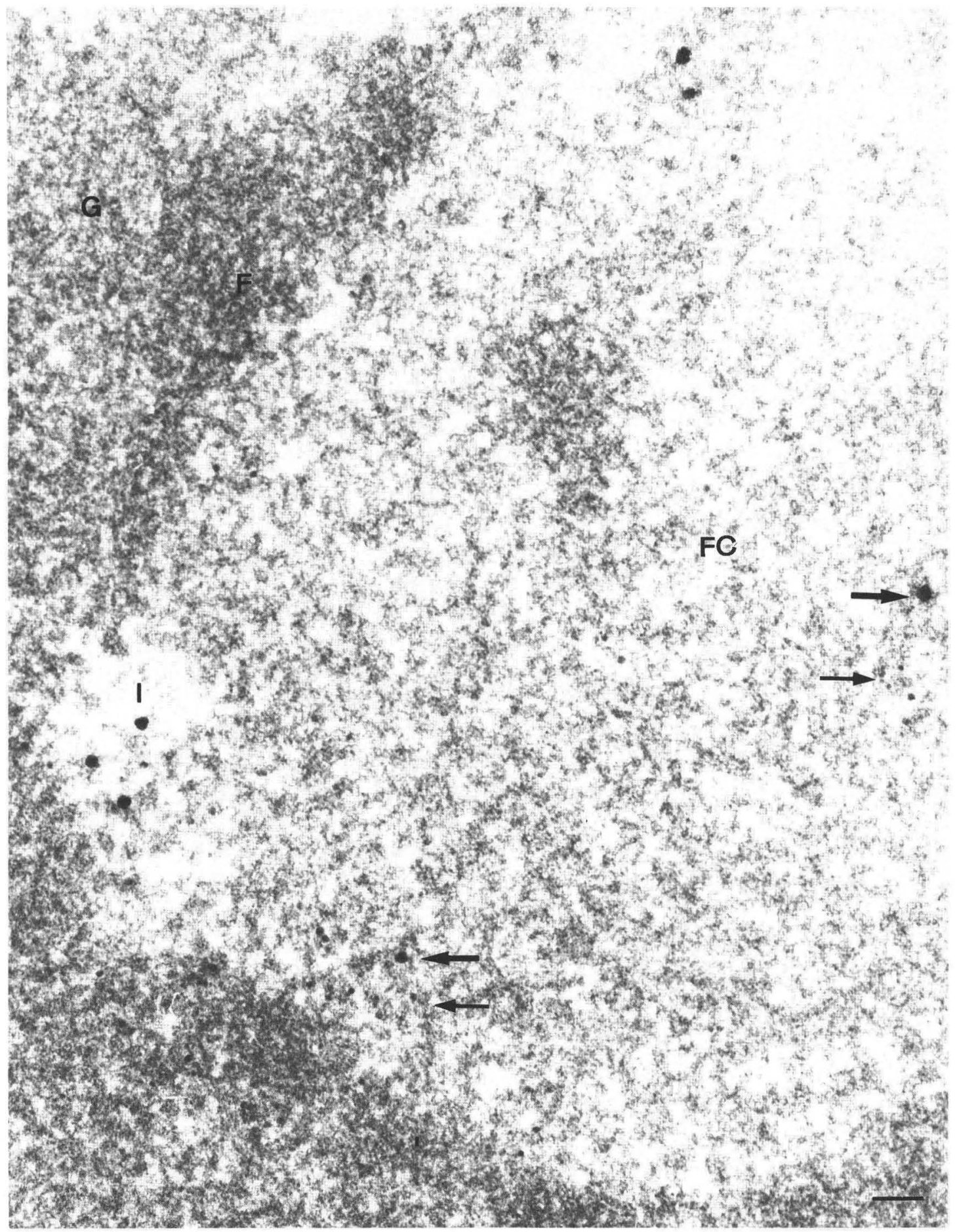

Fig. 9. Simultaneous immunolocalization of histone H4 (as revealed by small gold particles; small arrows) and DNA (as revealed by large gold particles; large arrows) on a section of Lowicryl-embedded Ehrlich tumor cells. In the nucleolus, histones and DNA can be colocalized inside the fibrillar center (FC), in interstices (I) surrounding the latter and in the associated chromatin (not shown in this figure). No labelling is observed on the the dense fibrillar component (F) and the granular component (G). Scale marker indicates $0.05 \mu \mathrm{m}$. 
Fig. 10c. The three components of the nucleolus are clearly recognized. Gold particles reflecting the distribution of RNA polymerase I are preferentially enriched over the fibrillar center while the surrounding dense fibrillar component as well as the granular component are not significantly labelled (Fig. 10c). Essentially identical results are obtained with a postembedding method using ultrathin frozen sections. To this end, rat PC12 cells were gently fixed with formaldehyde, infiltrated with sucrose and shock-frozen in liquid nitrogen (Scheer and Raska, 1987; Raska et al., 1989). Ultrathin cryosections were then incubated with RNA polymerase I antibodies followed by appropriate secondary antibodies coupled to colloidal gold. The result is presented in Fig. 11. Again, gold particles are selectively enriched over the large fibrillar center while the other nucleolar components are not labelled above background. In this context, it is worth mentioning that the other nucleolar components are fully accessible to antibodies under the same experimental conditions. This has been shown with antibodies reacting with various constituents of the dense fibrillar component as well as the granular component (e.g. Schmidt-Zachmann et al., 1984; Hügle et al., 1985; Reimer et al., 1987a; Raska et al., 1989).

\section{B. Immunolocalization of DNA Topoisomerase I}

DNA topoisomerase I has been implicated in transcriptional and replicational events (for review see Wang, 1985). A number of studies have indicated that this enzyme which interconverts topological isomers of DNA by breaking and resealing one DNA strand, is required for proper transcription of rRNA genes (e.g. Garg et al., 1987; Egyhazi and Durban, 1987; Rose et al., 1988; Zhang et al., 1988; Kim and Wang, 1989). Topoisomerase I has been shown to be associated with RNA polymerase I (Rose et al., 1988) and is located within the transcribed region of the rRNA genes but absent from the spacer region (Zhang et al., 1988). Immunofluorescence microscopy shows that DNA topoisomerase I molecules occur throughout the nucleoplasm of cultured rat cells but are preferentially enriched in the nucleoli (Fig. 12a'). The nucleolar fluorescence reveals a distinctly punctate pattern resembling that obtained with antibodies to RNA polymerase I (compare Figs 12 $\mathrm{a}^{\prime}$ and $\left.10 a^{\prime}\right)$. When analyzed at the electron microscopic level, DNA topoisomerase I is found enriched in the peripheral regions of the fibrillar centers, close to the surrounding dense fibrillar component (Fig. 13). The extranucleolar distribution of gold particles corresponds to the uniform labelling of the nucleoplasm as seen in immunofluorescence microscopy (Fig. 12a') and probably reflects the association of topoisomerase I with genes being actively transcribed by RNA polymerase II (see Wang, 1985).

\section{V. rDNA LOCALIZATION BY IN SITU HYBRIDIZATION}

A powerful tool for localizing specific DNA sequences within the cell is the in situ hybridization technique performed on cytological preparations (John et al., 1969; Gall and Pardue, 1969). The application of in situ hybridization at the light microscopic level has revealed the presence of rDNA in the nucleoli of numerous cell types (for review see Hennig, 1973). Specifically, the rDNA sequences appear to be restricted to some discrete areas in the nucleolus (Wachtler et al., 1986; Jimenez-Garcia et al., 1989; Rawlins and Shaw, 1990). Based on in situ hybridization with a radioactive probe, Arroua et al. (1982) reported that, in segregated nucleoli of human spermatocytes at late pachytene, the distribution of the silver grains corresponded to the position of the fibrillar centers. On the contrary, in human Sertoli cell nucleoli, which also display a segregated arrangement of their components, the pattern of in situ hybridization of a biotinylated probe to rDNA was taken as evidence that the distribution of rDNA corresponded to the dense fibrillar component rather than to the fibrillar centers (Wachtler et al., 1989). In a recent study, Rawlins and Shaw (1990) used a biotinylated cDNA probe to describe the three-dimensional organization of rDNA in nucleoli from pea root tips. They concluded that the observed fluorescing chain of small intranucleolar spots corresponded to rDNA present in fibrillar centers. 

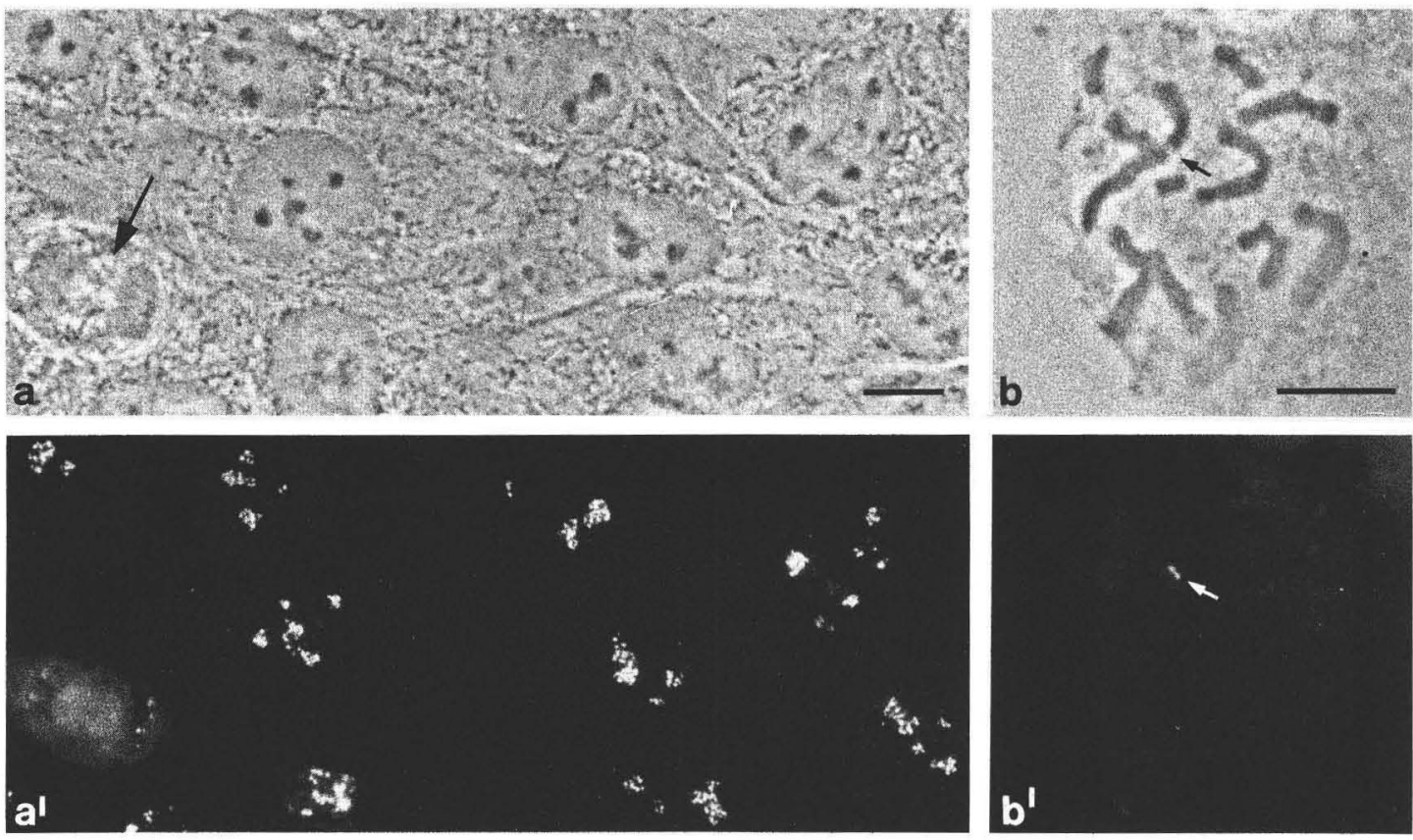

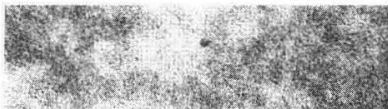

S.7.

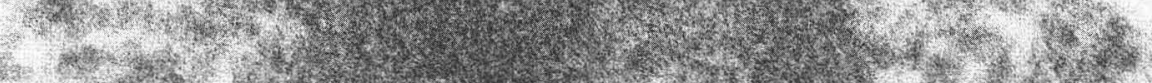

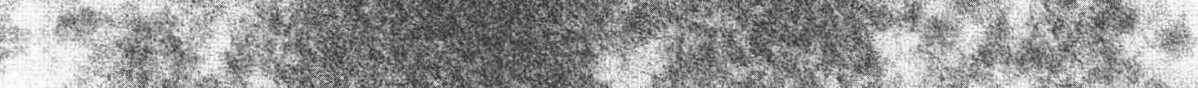

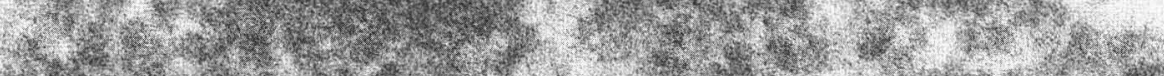

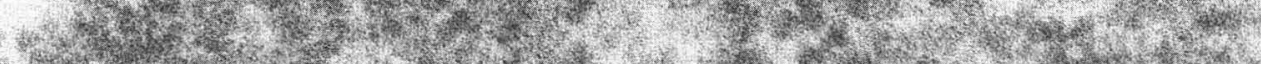

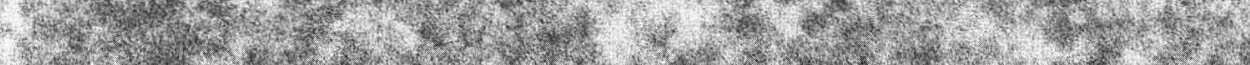

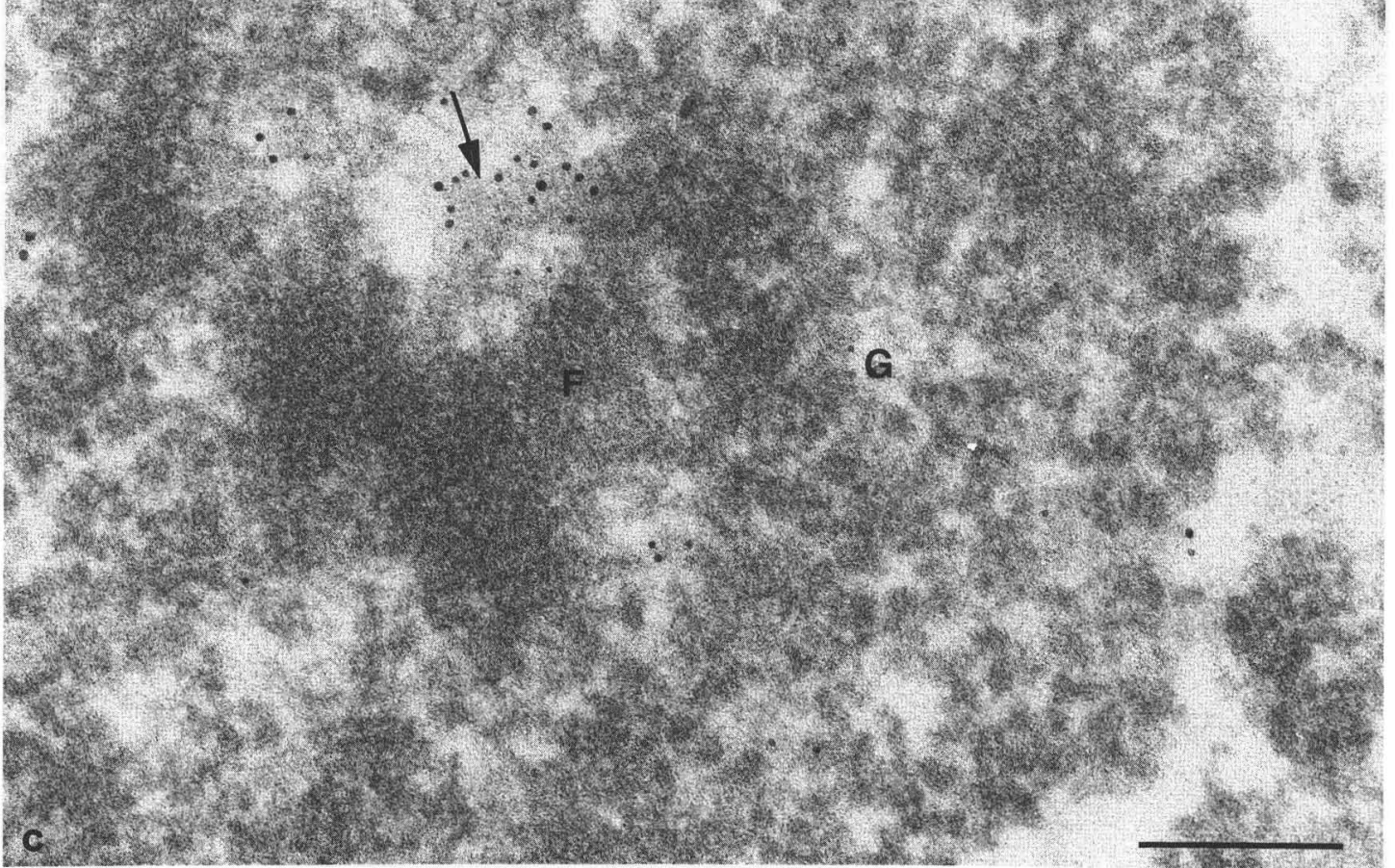

Fig. 10 
Thus, it appears that the precise localization of rDNA requires higher resolution that is attainable only with electron microscopic procedures. While the in situ hybridization technique at the light microscope level has become a standard method for the localization of DNA sequences in tissue sections or cultured cells, its application at the electron microscope level has only rarely been described (for reviews see: Geuskens, 1977; Hutchison, 1984).

Early attempts to hybridize tritiated labelled 28S rRNA to rDNA of mouse L cells suggested that ribosomal cistrons were present in both intranucleolar and perinucleolar chromatin (Jacob et al., 1974). Since for a long time the in situ hybridization procedure could only be performed with radioactive probes and by means of autoradiography, the spatial resolution was necessarily limited. The introduction of non-radioactive labelling methods of the hybridization probes in conjunction with immunological detection procedures improved the resolution considerably and furthermore allowed a rapid signal detection (Langer-Safer et al., 1982; Hutchison et al., 1982; Binder et al., 1986).

Recently, a biotinylated rDNA probe was hybridized in situ to ultrathin sections of Ehrlich tumour cells for precise localization of rDNA (Thiry and Thiry-Blaise, 1989). An Eco R1-Sal 1 fragment of $1.9 \mathrm{~kb}$ containing $1.45 \mathrm{~kb} 18 \mathrm{~S}$ rDNA (Grummt and Gross, 1980) inserted into the pBR322 plasmid was used. In order to avoid any cross hybridization to rRNA, only the sense-strand of the mouse rDNA frament was biotinylated by nick translation. This probe was hybridized to Lowicryl sections of cells and the hybrids were then detected by anti-biotin antibodies followed by secondary antibodies coupled to colloidal gold. In order to allow effective denaturation of the DNA contained in the tissue section, appropriate fixation conditions have to be chosen. The fixative has, on one hand, to preserve the ultrastructure from the effect of the agressive denaturation agents (Barbera et al., 1979; Raap et al., 1986) and, on the other hand, to allow DNA denaturation. In order to find out the ideal fixation and DNA denaturation conditions, an immunocytochemical approach was employed based on the use of an antibody reacting selectively with single-stranded DNA (for details see Thiry and Thiry-Blaise, 1989).

Using optimized in situ hybridization conditions, gold labelling is restricted to Ehrlich tumour cell nucleoli. Gold particles are visualized in the fibrillar centers, preferentially at their peripheral regions, and in some intranucleolar clumps of condensed chromatin which are in contact with the fibrillar centers. They are, however, absent from the dense fibrillar component and the granular component (Fig. 14).

\section{DISCUSSION}

The main goal of this review is to discuss data obtained by immunogold electron microscopy and ultrastructural in situ hybridization approaches and their implications concerning the location and composition of nucleolar chromatin containing the rRNA genes.

However, an objective interpretation of the results obtained is only possible when the limitations of immunocytochemical methods used are taken into account. Consequently, before discussing the functional organization and spatial distribution of chromatin associated with the nucleolus, we want to begin with a critical analysis of

Fig. 10. Localization of RNA polymerase I by immunofluorescence microscopy ( $\left.a^{\prime}, b^{\prime}\right)$ and immunogold electron microscopy (c). Cultured rat cells grown on coverslips were incubated with rabbit antibodies to RNA polymerase I followed by FITC-labelled secondary antibodies and photographed with phase contrast optics (a)) or epifluorescence illumination $\left(a^{\prime}\right)$. Note the punctate pattern of intranucleolar fluorescence and the distinct NOR-staining of metaphase chromosomes (rat cells have 3 NOR-bearing chromosome pairs; a mitotic cell is indicated by the arrow in (a). In isolated metaphase chromosomes from PtK2 cells (derived from a male rat kangeroo), the NOR of the large X-chromosome is the only site of fluorescence (arrow in b'; note the separated spots per chromatid; for details see Scheer and Rose, 1984). The corresponding phase contrast image is shown in (b). Immunogold electron microscopic detection of RNA polymerase I in the nucleolus of rat liver is shown in (c) (preembedding protocol). Gold particles are selectively enriched in the fibrillar center (arrow). Dense fibrillar component (F); granular component (G). Scale markers indicate $10 \mu \mathrm{m}(\mathrm{a}, \mathrm{b})$ and $1 \mu \mathrm{m}(\mathrm{c})$. 


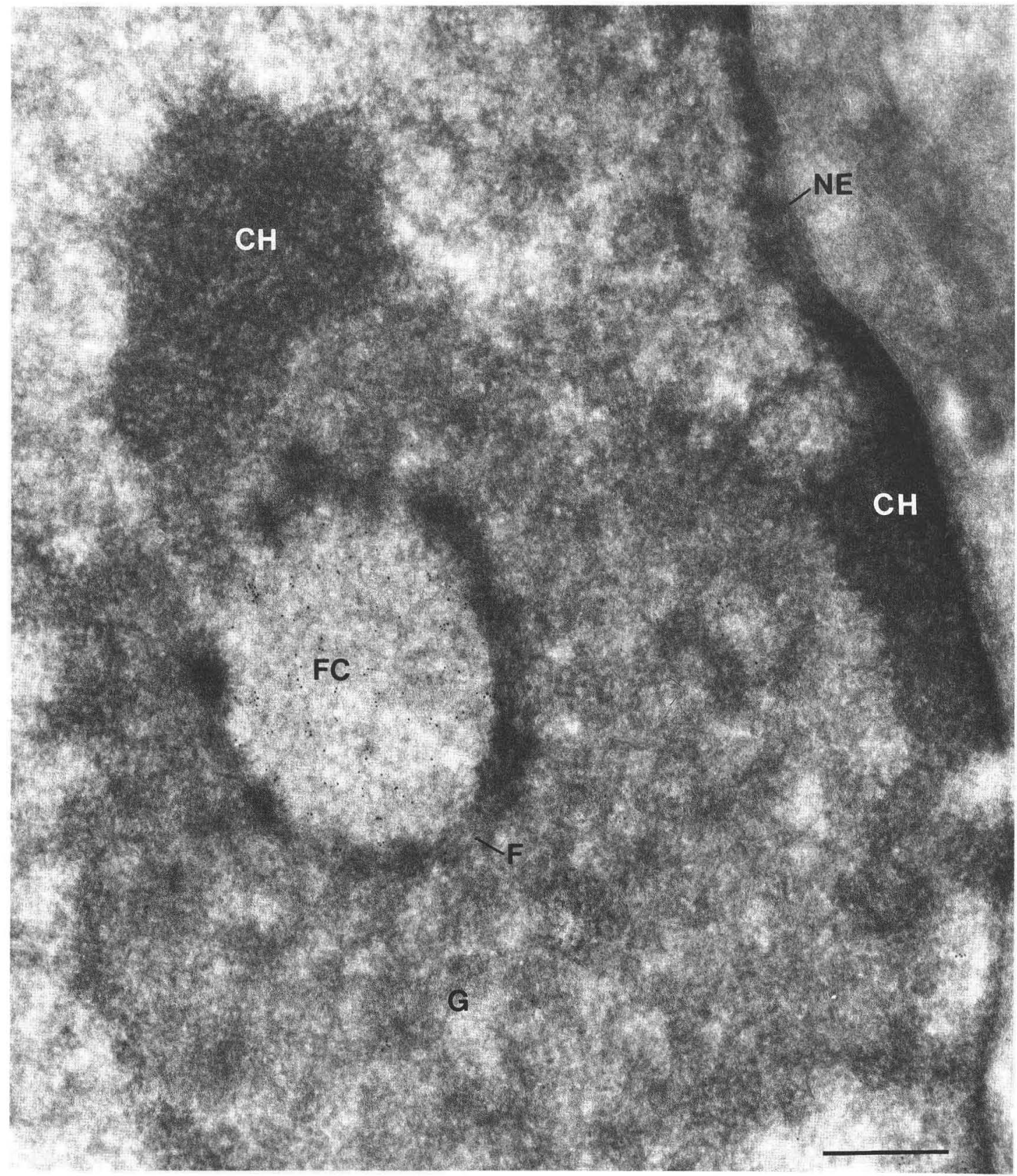

Fig. 11. Electron micrograph showing the labelling of an ultrathin cryosection of cultured rat PC12 cells with autoantibodies to RNA polymerase I (for details see: Reimer et al., 1987b; Scheer and Raska, 1987). Gold particles are enriched over the large fibrillar center (FC) and almost absent from the surrounding dense fibrillar component $(F)$ and the granular component $(\mathrm{G})$. Chromatin $(\mathrm{CH})$, nuclear envelope (NE). Scale marker indicates $1 \mu \mathrm{m}$. Courtesy of Dr Ivan Raska. 

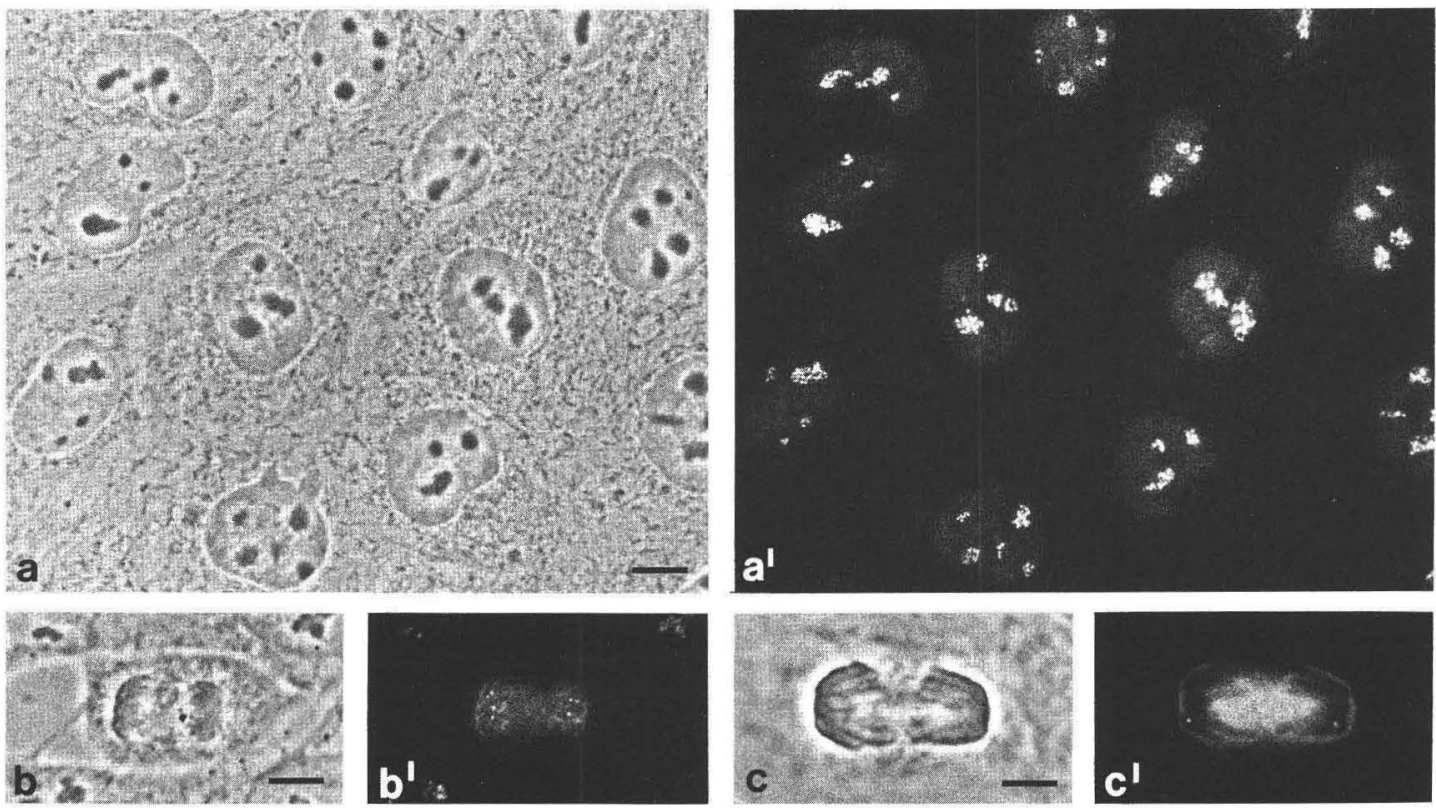

Fig. 12. Immunofluorescence microscopical localization of DNA topoisomerase I on cultured rat cells (for details see Rose et al., 1988). Besides a strong nucleolar signal, a diffuse staining of the whole nucleoplasm is noted (( $\left.\mathrm{a}^{\prime}\right)$ the corresponding phase contrast micrograph is shown in (a)). In mitotic cells the NORs of the chromosomes are clearly labelled ((b') rat cell with 3 NOR-bearing chromosome pairs; ( $c^{\prime}$ ) PtK2 cell derived from a male rat kangaroo; the NOR is located on the X-chromosome, cf. Howell, 1982)). The corresponding phase contrast images are presented in (b) and (c), respectively. Scale markers indicate $10 \mu \mathrm{m}$.

immunoelectron microscopic techniques relevant in the context of the present study (for a comprehensive synopsis of electron microscopical immunocytochemical techniques see, e.g., Polak and Varndell, 1984).

\section{A. Potential Value and Limitations of Immuno- electron Microscopic Techniques}

Immunocytochemistry of the nucleolus is confronted with the problem of obtaining a clear distinction between the various nucleolar components as well as retention of their antigenicity. However, these two requirements are not always compatible since fixation conditions necessary for a good ultrastructural preservation of the nucleolus can alter the antigenicity of nucleolar elements thus preventing the use of immunocytochemistry. Various immunoelectron microscopic techniques have been developed to obtain practicable compromises between these two requirements.

\section{Preembedding labelling procedures}

In the preembedding labelling procedures, the antibody binding reaction is performed on cryosections of tissues or cell pellets or on permeabilized cells grown on coverslips prior to fixation, dehydration and plastic embedding, all of which have an adverse influence on the antigen preservation (Roth et al., 1981). However, as previously stressed by Priestley (1984), a major disadvantage of the preembedding labelling might be the slow penetration of the antibodies into the relatively thick $(5 \mu \mathrm{m})$ cryosections or cell monolayers. The variations of the labelling pattern of the fibrillar centers with the monoclonal anti-DNA antibody as a function of their state of preservation is probably related to this problem (Thiry et al., 1988).

In evaluating results obtained with the preembedding protocol, several considerations must be kept in mind. One may ask, for instance, whether the absence of gold particles in the dense 


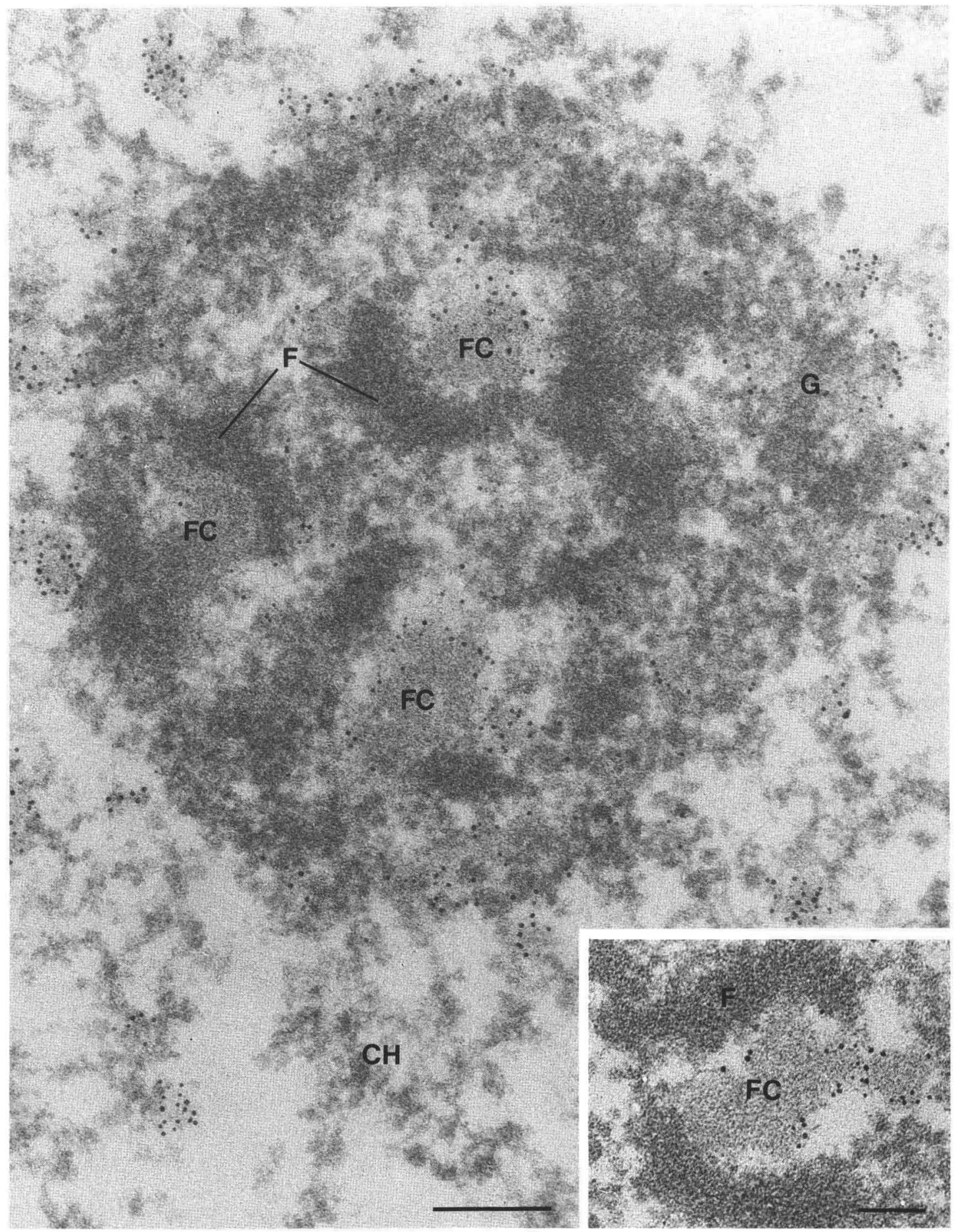

Fig. 13. Immunogold electron microscopical localization of DNA topoisomerase I (preembedding protocol). A frozen section $(5 \mu \mathrm{m})$ of rat liver was incubated with affinity purified antibodies to topoisomerase I (see Rose et al., 1988) followed by secondary antibodies coupled to $5 \mathrm{~nm}$ gold particles. After fixation and Epon embedding, ultrathin sections were cut. Gold particles are preferentially located at the periphery of the fibrillar centers (FC). The insert shows the gold-decorated boundary region between a fibrillar center and the surrounding dense fibrillar component (F) at higher magnification. The labelling of the perinucleolar chromatin $(\mathrm{CH})$ indicates the presence of the enzyme on transcribing protein-coding genes. Granular component (G). Scale markers indicate $1 \mu \mathrm{m}$ and $0.5 \mu \mathrm{m}$ (insert). 


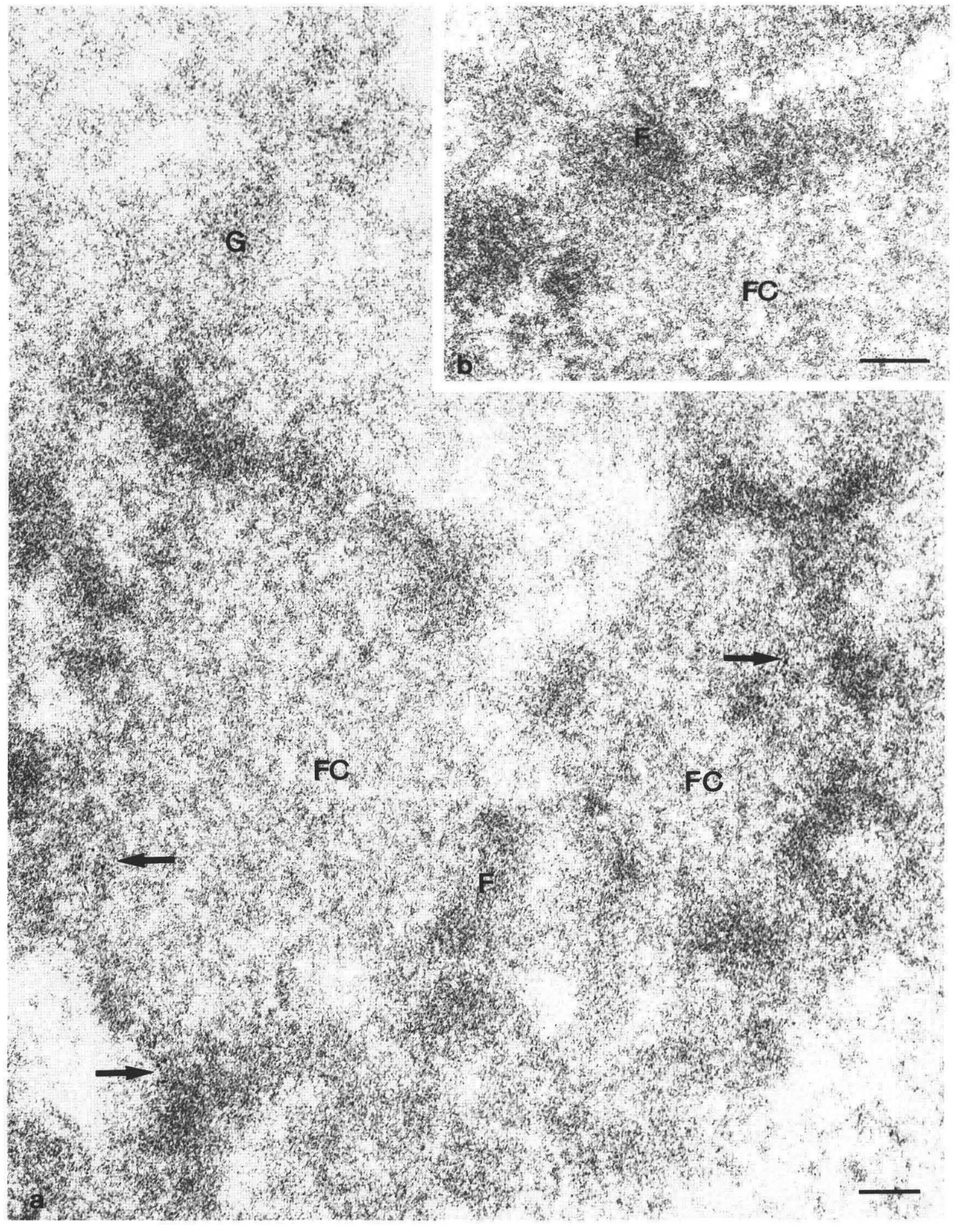

Fig. 14. rDNA/rDNA hybridization on Lowicryl sections of Ehrlich tumour cell nucleoli. (a) General view showing gold particles in the fibrillar centers (FC). (b) Detail of the peripheral region of a fibrillar center. Gold particles are preferentially visualized at the boundary region between the fibrillar centers and the dense fibrillar component (F), even when dense fibrillar component is located inside the fibrillar centers. Dense fibrillar component $(\mathrm{F})$ and granular component $(\mathrm{G})$ are completely devoid of gold particles. Scale markers indicate $0.1 \mu \mathrm{m}$. 
fibrillar component, as observed with the polyclonal anti-RNA polymerase I antibody (Scheer and Rose, 1984) or with the monoclonal anti-DNA antibody (Scheer et al., 1987; Thiry et al., 1988) does reflect a true absence of the cognate antigens in this nucleolar region or results from a hindered accessibility of immunoglobulins. Indeed, while a positive immunolocalization signal indicates the presence of a specific antigen in a given cellular compartment, the absence of immunocytochemical reactivity does not a priori imply the absence of the corresponding antigen. Modifications, conformational alterations, selective masking or inaccessibility of antigenic determinants may also produce negative results. Consideration of these possibilities is particularly relevant when working with monoclonal antibodies or with conventional antibodies directed against defined peptides. Therefore, it is indicated to complement results obtained by preembedding techniques with postembedding labelling approaches.

The problem of antigen accessibility is accentuated when using monoclonal antibodies of the IgM class; these antibodies have a molecular weight of approximately 900,000 as compared to $\pm 165,000$ in case of IgG molecules. In addition, a restricted penetration of the relatively large gold particles with the attached secondary antibodies or protein A molecules used to reveal the primary antibodies has also to be taken into account (see later). However, using scleroderma autoantibodies, gold-antibody complexes were detected over the dense fibrillar component, indicating that this nucleolar region is in fact accessible to antibodies and antibody-gold complexes (Scheer and Rose, 1984). Furthermore, in order to locate RNA polymerase I, Scheer and Rose (1984) employed polyclonal antibodies which generally recognize multiple epitopes of a specific antigen, thereby reducing complications arising from epitope alterations or masking.

The preembedding labelling procedure has the great advantage to allow immunoreactions on biological material without prior chemical fixation. However, the use of mild detergents such as Triton X-100 or treatment with cold aceton to allow penetration of antibodies into the cell interior might lead to some alterations and partial degradation of subcellular structures as well as to rearrangements of antigens. Thus, with this technique chromatin often appears decondensed, the fibrillar centers are in a more loosened configuration and the boundaries between the various nucleolar constituents are less clear (Thiry et al., 1988).

\section{Postembedding labelling procedures}

Many drawbacks inherent in the preembedding method, in particular the preservation of relationships between the various nucleolar components, may be overcome by the postembedding procedure. In this case however, several other problems arise from the need to stabilize the biological material by fixation and the embedding process itself.

The first one is that the matrix of the resin hinders entry of antibodies into ultrathin sections. In fact, using transverse sectioning of plastic embedded ultrathin immunolabelled sections, it has been shown that only the antigenic sites exposed at the surface of the section can be revealed by immunogold techniques (Bendayan et al., 1987; Stierhof and Schwarz, 1988). This may be a limitation particularly when antigens present in low amounts are to be detected. However, the successful labelling of various membrane proteins, some of them being present in very small amounts, speaks in favor of the high sensitivity of the technique (Bendayan, 1984). Since there is no penetration of labelled antibodies into the section, the accessibility of antigens with dimensions below the thickness of the section is variable and depends on the specific position of the antigen in the section. In the case of the double immunolabelling procedure involving each face of an ultrathin section (see Section III), both labelled antigens are therefore separated by the thickness of the section.

Secondly, the preservation of antigenicity of the biological material and the steric hindrance of antibodies, in particular of antibody-gold complexes, imposes several criteria on resin selection. Thus, the chemical reactivity of the cured resin, its method of curing and the degree of crosslinking are important parameters (Causton, 1984). Acrylate resins, such as Lowicryl K4M (Roth et 
al., 1981; Armbruster et al., 1982, 1983; Carlemalm et al., 1982, 1985; Altman et al., 1984; Kellenberger et al., 1987) and LR White (Newman et al., 1982, 1983a,b; Craig and Miller, 1984; Newman and Jasani, 1984; Newman and Hobot, 1987), have some advantages for postembedding staining over epoxy resins. They are hydrophilic and tolerate water during polymerization, hence dehydration of specimens need not be so stringent. The acrylate resins are also very mobile allowing infiltration of biological material even at low temperature and are thus very suitable for techniques requiring low temperature antigen preservation. Contrary to epoxy resins, there are less chemical interactions between the resin and the antibody, thus resulting in a significantly lower background labelling. The contradictory results obtained by Derenzini et al. (1985) and by Thiry and Muller (1989) concerning the spatial distribution of histones within the nucleolus may be due to differences in the choice of the resin.

\section{Immunocryoultramicrotomy}

For the localization of a number of cellular antigens, immunocytochemical techniques involving ultrathin sections of embedded biological material can be quite successfully applied. However, numerous antigens such as RNA polymerase I loose their antigenicity under these conditions (Scheer and Rose, 1984) and require alternative approaches for their immunodetection. In the case of immunocryoultramicrotomy, the immune reaction is performed on thawed ultrathin sections of fixed material which are then embedded in a thin layer of methylcellulose (Tokuyasu, 1978, 1980, 1984, 1986). This technique combines the advantages of excellent antigenic preservation, very high sensitivity and direct accessibility of antibodies to intracellular structures. This approach has allowed us to study the location of RNA polymerase I (Raska and Scheer, 1987; Reimer et al., 1987a,b; Raska et al., 1989) and DNA topoisomerase I (Raska et al., 1989) in cell nucleoli. However, as with sections of resin-embedded material, gold complexes do not penetrate into the cryosections (Barbossa and Da Silva, 1986a,b). Furthermore, cryoultramicrotomy requires chemi- cal fixation prior to the immune reaction which may destroy the antigenicity. The method of freeze-substitution used in conjunction with Lowicryl seems to be very promising in order to avoid this fixation problem (Carlemalm et al., 1985; Acetarin et al., 1986a,b, 1987).

\section{Colloidal gold labelling}

Colloidal gold used as a tracer offers many advantages. The high contrast of gold particles considerably facilitates their identification and excludes the fact that they are confounded with other elements of the biological material. The resolution obtainable by such particulate tracers is superior to cytochemical methods involving enzymes such as peroxidase (Courtoy et al., 1983). Furthermore, gold particles of various sizes can be easily produced (Horisberger, 1979; Slot and Geuze, 1981, 1985; Roth, 1982b) and, owing to the great size homogeneity of the particle populations, double-labelling experiments can be performed on the same preparation.

Gold particles coupled with secondary immunoglobulins are most commonly used. As a rule, the density of marking achieved is superior with indirect procedure since, in principle, several markers can bind to a single primary antibody and hence provide an amplification effect. Protein A-gold probes are also used in immunoelectron microscopic approaches. However, their use is somewhat restricted since they do not react, for instance, with murine immunoglobulins.

The size of gold particles is important in immunocytochemical studies. Quantitative analysis clearly showed that labelling intensity is inversely proportional to the size of gold particles, suggesting that small gold particles are more suitable for detection of substances present in low concentrations (Yokota, 1988). Optimal resolution also requires the smallest possible gold particles. Gold particles in the $3-5 \mathrm{~nm}$ category are generally considered as ideal markers in electron microscopic immunocytochemistry. Their diameters are smaller than the size of $\mathrm{IgG}$ molecules (about $8 \mathrm{~nm}$; Roth, 1982a). Therefore, steric hindrances of gold particles during immunolabelling are relatively inconsequential when compared to those of $\mathrm{IgG}$ 
molecules. However, the gold particles may impair biological activities of the antibody if their binding sites interfere with functional sites such as those required for antigen binding or interactions with Fc-receptors. Tischendorf and Kapfer (1988) recommended the use of $5 \mathrm{~nm}$ gold particles rather than gold particles of $3 \mathrm{~nm}$ diam. because the former are a label much more neutral to the function of the antibody. On the other hand, the resolution (distance between the antigen and center of the gold particle) is tributary to the number of layers involved in the immunocytochemical procedures used. In the case of indirect methods using two layers, the poorest theoretical resolution, not taking into account the size of the probe, is nearly similar for both the immunogold staining technique $(16 \mathrm{~nm})$ and the protein $\mathrm{A}$-gold technique $(13 \mathrm{~nm}$; the length of a protein A molecule is approximately $5 \mathrm{~nm}$ ). Nevertheless, the presentation of the antigen, the molecule type involved in each layer of the immunocytochemical technique, the angle formed between the different molecules of multiple layers, the position of the marker on the labelled molecule should also be parameters to take into consideration.

\section{Specificity of the methods}

Reliable immunocytochemical results can only be obtained with high quality and carefully characterized antibodies (review in De Mey, 1983). Furthermore, the specificity of the staining reaction has to be critically examined (Childs, 1983; Bendayan, 1984; Gosselin et al., 1986). This can be done by employing various labelling regimes with differently fixed and processed specimens, including immunofluorescence microscopy. As a routine control, the primary antibodies should be omitted or, better, replaced by irrelevant antibodies of the same immunoglobulin subclass. Furthermore, a careful quantitative evaluation of the background signals is imperative.

\section{B. Functional Organization of the Nucleolus}

From the evidence presented in this review it now appears that transcription of the rRNA genes occurs exclusively in the fibrillar centers of mam- malian nucleoli. This conclusion is in agreement with earlier observations based on a variety of methods (for review see Goessens, 1984) and is also compatible with recent results obtained with plant nucleoli (e.g. Martin et al., 1989; Jordan and Rawlins, 1990). Our experimental data which are based on immunolocalization and in situ hydridization procedures at the electron microscopic level clearly show that the fibrillar centers are the sole nucleolar structures where rDNA, core histones and enzymes, involved in rDNA transcription are located together.

Earlier autoradiographic studies of cells pulselabelled with radioactive uridine have shown that the dense fibrillar component is the first structure to be clearly marked by silver grains. Accordingly, the authors concluded that transcription of the rRNA genes takes place in this nucleolar compartment (for reviews see: Fakan, 1978, 1986; Goessens, 1984). However, it should be kept in mind that the position of the silver grains in autoradiograms does not necessarily coincide with the source of the radioactivity (Williams, 1977). Another point of consideration must be the fact that pre-rRNA molecules which have incorporated radioactive uridine, terminate continuously throughout the labelling period, even after extremely short pulses. The shortest labelling times applied ranged from about 2 to $5 \mathrm{~min}$, i.e. a time span required for single RNA polymerase I molecule to transcribe half or even entirely through a rRNA gene unit. Thus it is conceivable that the distribution of silver grains primarily reflects the sites where the template-released pre-rRNA molecules accumulate to high local concentrations, thereby facilitating their detection by autoradiography (Goessens, 1976; Scheer and Raska, 1987; Scheer and Benavente, 1990). Of course, the rRNA transcription units must also be labelled but the resulting silver grains in the fibrillar centers probably escaped detection so far because of a low signal to noise ratio. In this context, it is important to mention that in situ hybridization of a rDNA probe allowed detection of rRNA inside the fibrillar centers, preferentially towards their peripheral regions (Thiry and Thiry-Blaise, 1989).

Taken together, we feel that the critical analysis of data obtained till now justifies the conclusion 
that transcription of the rRNA genes takes place within the confines of the fibrillar centers, probably close to the boundary regions to the surrounding dense fibrillar component. It is interesting to note that the 'heart' of the nucleolus, i.e. the fibrillar centers harboring the rRNA transcriptional apparatus, does not disintegrate during mitosis as is the case with the other nucleolar components. Based on morphological similarities and the presence of argyrophilic proteins, it is well established that fibrillar centers and the NORs of metaphase chromosomes are, at least partly, equivalent structures (for Refs see Goessens, 1984). In fact, we have shown that key enzymes involved in transcription of rRNA genes such as polymerase I (Fig. 10; Scheer and Rose, 1984) and topoisomerase I (Fig. 12; Rose et al., 1988; see also Guldner et al., 1986) remain bound to the NORs during mitosis. Apparently rRNA genes together with the essential transcriptional machinery (perhaps in the form of 'frozen' transcriptional complexes) are transmitted from one cell generation to the next one, thereby ensuring a rapid reactivation of rRNA transcription following mitosis. Commencement of transcription then triggers reformation of the nucleolus beginning with the coalescence of preformed 'prenucleolar bodies' around the NOR/fibrillar center which results in the formation of a surrounding dense fibrillar layer (Benavente et al., 1987). Selective inhibition of rRNA transcription by microinjection of antibodies to RNA polymerase I into mitotic or interphasic mammalian cells have clearly shown that ongoing transcription is required for the integration of the dense fibrillar component into the nucleolus (Benavente et al., 1987, 1988). Furthermore, these experiments have demonstrated that the dense fibrillar component represents a structure sui generis which exists independent of the transcriptional apparatus (for review see Scheer and Benavente, 1990). Consequently, this nucleolar component cannot be considered as a transient structure formed by the superposition of active rRNA genes and their transcripts.

We propose that, after release from the rDNA, the primary transcripts are rapidly translocated to and accumulated in the surrounding dense fibrillar component where they are transiently stored and where early RNA processing and protein-RNA assembly occurs. In this respect, as recently discussed by Scheer and Benavente (1990), both fibrillar nucleolar components might be considered as a functional unit whose structural integrity is essential for the transition of the primary transcripts from the template-bound to the released state. Subsequent steps of assembly and maturation then occur in the granular component before the ribosomal subunits are finally transported through the nuclear pores complexes into the cytoplasm.

Acknowledgements - We thank Hilde Merkert, Francine Skivée and Jean-Claude Paulus for expert technical assistance. This work received financial support from the Belgian Government (ARC no. 85-90-80), from the Deutsche Forschungsgemeinschaft (SFB 165) and from the "Fonds National de la Recherche Médicale" of Belgium (no. 3.4512.86 and 3.4512.90). M.T. is "Chargé de Recherches auprès du FNRS".

\section{REFERENCES}

Acetarin, J. D., Carlemalm, E. and Villiger, W., 1986a. Development of new Lowicryl resins for embedding biological specimens at even lower temperatures. J. Microsc. Oxford, 143, 81-88.

Acetarin, J. D., Villiger, W. and Carlemalm, E., $1986 \mathrm{~b}$. A new heavy-metal-containing resin for low temperature embedding and imaging of unstained sections of biological material. J. Electron Microsc. Techn., 4, 257-264.

Acetarin, J. D., Carlemalm, E., Kellenberger, E. and Villiger, W., 1987. Correlation of some mechanical properties of embedding resins with their behavior in microtomy. J. Electron Microscopy Techn., 6, 63-79.

Altman, L., Schneider, B. and Papermaster, D., 1984. Rapid embedding of tissues in Lowicryl K4M for immunoelectron microscopy. J. Histochem Cytochem., 32, 1217-1223.

Arana, R. and Seligmann, M., 1967. Antibodies to native and denatured deoxyribonucleic acid in systemic lupus erythematosus. J. clin. Invest., 46, 1867-1882.

Armbruster, B., Carlemalm, E., Chiovetti, R., Garavito, R., Hobot, J., Kellenberger, E. and Villiger, W., 1982. Specimen preparation for electron microscopy using low temperature embedding resins. J. Microsc. Oxford, 126, 77-85.

Armbruster, B., Garavito, R. and Kellenberger, E., 1983. Dehydration and embedding temperatures affect the antigenic specificity of tubulin and immunolabelling by the protein A-colloidal gold technique. J. Histochem. Cytochem., 31, 1380-1384.

Arroua, M., Hartung, M., Devictor, M., Berger-Lefran, J. and Stahl, A., 1982. Localization of ribosomal genes by in situ hybridization in the fibrillar centre of the nucleolus in human spermatocyte. Biology of the Cell, 44, 337-340. 
Barbera, E., Caliani, M., Pages, M. and Alonso, C., 1979. Chromosomal DNA denaturation and reassociation in situ. Expl Cell Res., 119, 151-162.

Barbosa, M. L. F. and Da Silva, P. P., 1986a. Ultrastructural patterns of ferritin permeation into glutaraldehyde-fixed freeze-fractured sarcomeres characterize stages of contraction in striated muscle. J. Electron Microsc. Techn., 4, 329-342.

Barbosa, M. L. F. and Da Silva, P. P., 1986b. Fracturepermeation: a technique to assess cytoplasm compactness after glutaraldehyde-fixation. J. Electron Microsc. Techn., 4, 385-397.

Benavente, R., Reimer, G., Rose, K., Hügle-Dörr, B. and Scheer, U., 1988. Nucleolar changes after microinjection of antibodies to RNA polymerase I into the nucleus of mammalian cells. Chromosoma, 97, 115-123.

Benavente, R., Rose, K., Reimer, G., Hügle-Dörr, B. and Scheer, U., 1987. Inhibition of nucleolar reformation after microinjection of antibodies to RNA polymerase I into mitotic cells. J. Cell Biol., 105, 1483-1491.

Bendayan, M., 1984. Protein A-gold electron microscopic immunocytochemistry: methods, applications and limitations. J. Electron Microsc. Techn., 1, 243-270.

Bendayan, M., Nanci, A. and Kan, F., 1987. Effect of tissue processing on colloidal gold cytochemistry. J. Histochem. Cytochem., 35, 983-996.

Binder, M., Tourmente, S., Roth, J., Renaud, M. and Gehring, W., 1986. In situ hydridization at the electron microscope level: localization of transcripts on ultrathin sections of Lowicryl K4M-embedded tissue using biotinylated probes and protein A-gold complexes. J. Cell Biol., 102, 1646-1653.

Carlemalm, E., Garavito, R. and Villiger, W., 1982. Resin development for electron microscopy and an analysis of embedding at low temperature. J. Microsc. Oxford, 126, 123-143.

Carlemalm, E., Villiger, W., Hobot, J. A., Acetarin, J. D. and Kellenberger, E., 1985. Low temperature embedding with Lowicryl resins: two new formulations and some applications. J. Microsc. Oxford, 140, 55-63.

Causton, B. E., 1984. The choice of resins for electron immunocytochemistry. In: Immunolabelling for Electron Microscopy, Polak, J. M. and Varndell, I. M. (eds.), Elsevier, Amsterdam, New-York, Oxford, 29-36.

Childs, G. V., 1983. The use of multiple methods to validate immunocytochemical stains. J. Histochem. Cytochem., 31, $168-176$.

Courtoy, P. J., Picton, D. H. and Farqumar, M. G., 1983. Resolution and limitation of the immunoperoxidase procedure in the localization of extracellular matrix antigens. J. Histochem. Cytochem., 31, 945-951.

Craig, S. and Miller, C., 1984. LR White resin and improved on-grid immunogold detection of vicilin, a pea seed storage protein. Cell Biol. int. Rep., 8, 879-886.

De Mey, J., 1983. Collolidal gold probes in immunocytochemistry. In: Immunocytochemistry, Polak, J. and Van Noorden, S. (eds.), Wright PSG, Bristol, London, Boston, 82-112.

Derenzini, M., Pession, A., Licastro, F. and Novello, F., 1985. Electron-microscopical evidence that ribosomal chromatin of human circulating lymphocytes is devoid of histones. Expl Cell Res., 157, $50-62$.

Egyhazi, E. and Durdan, E., 1977. Microinjection of antitopoisomerase I immunoglobulin $\mathrm{G}$ into nuclei of Chironomus tentans salivary gland cells leads to blackage of transcription elongation. Molec. cell. Biol., 7, 4308-4316.
Fakan, S., 1978. High resolution autoradiography studies on chromatin functions. In: The Cell Nucleus, Vol. 5, Busch, $\mathrm{H}$. (ed.), Academic Press, New York, 3-53.

Fakan, S., 1986. Structural support for RNA synthesis in the cell nucleus. Meth. Achiev. expl Pathol., 12, 105-140.

Gall, J. and Pardue, M., 1969. Formation and detection of RNA-DNA hybrid molecules in cytological preparations. Proc. natn. Acad. Sci. U.S.A., 63, 378-383.

Garg, L., Diangelo, S. and Jacob, S., 1987. Role of DNA topoisomerase I in the transcription of supercoiled rRNA gene. Proc. natn. Acad. Sci. U.S.A., 84, 3185-3188.

Geuskens, M., 1977. Autoradiographic localization of DNA in nonmetabolic conditions. In: Principles and Techniques of Electron Microscopy, Vol. 7, Hayat, M. (ed.), Van Nostrand Reinbold Co, New York, 163-201.

Gilliam, A. C., Lang, D. and Lospalluto, J. J., 1980. Antibodies to double-stranded DNA: purification and characterization of binding specificities. J. Immunol., 125, 874-885.

Goessens, G., 1976. High resolution autoradiographic studies of Ehrlich tumour cell nucleoli. Expl Cell Res., 100, 88-94.

Goessens, G., 1984. Nucleolar Structure. Int. Rev. Cytol., 87, $107-158$

Gosselin, E., Cate, C., Pettengill, O. and Sorenson, G., 1986. Immunocytochemistry: its evolution and criteria for its application in the study of epon-embedded cells and tissue. Am. J. Anat., 175, 135-160.

Gratzner, H., 1982. Monoclonal antibody to 5-bromo and 5-iodo-deoxyuridine: a new reagent for detection of DNA replication. Science, 218, 474-475.

Grummt, I. and Gross, H., 1980. Structural organization of mouse rDNA: comparison of transcribed and nontranscribed regions. Molec. gen. Genet., 177, 223-229.

Guldner, H-H., Szostecki, C., Vosberg, H-P., Lakomek, H-J., Penner, E. and Bautz, F., 1986. Scl 70 autoantibodies from scleroderma patients recognize a $95 \mathrm{kDa}$ protein identified as DNA topoisomerase I. Chromosoma, 94, 132-138.

Hadjiolov, A., 1985. The nucleolus and ribosome biogenesis. In: Cell Biology Monographs, Vol. 12, Springer-Verlag, Wien, New York, 1-263.

Hennig, W., 1973. Molecular hybridization of DNA and RNA in situ. Int. Rev. Cytol., 36, 1-44.

Horisberger, M., 1979. Evaluation of colloidal gold as a cytochemical marker for transmission and scanning electron microscopy. Biology of the Cell, 36, 253-258.

Howell, W. M., 1982. Selective staining of nucleolus organizer regions (NORs). In: The Cell Nucleus, Vol. 11, Busch, H. and Rothblum, L. (eds.) Academic Press, New York, 89-142.

Hügle, B., Hazan, R., Scheer, U. and Franke, W., 1985. Localization of ribosomal protein $\mathrm{S} 1$ in the granular component of the interphase nucleolus and its distribution during mitosis. J. Cell Biol., 100, 873-886.

Hutchison, N., 1984. Hybridisation histochemistry: In situ hybridisation at the electron microscope level. In: Immunolabelling for Electron Microscopy, Polak, J. and Varndell, I. (eds.), Elsevier, Amsterdam, New York, Oxford, 341-351.

Hutchison, N., Langer-Safer, P., Ward, D. and Hamkalo, B., 1982. In situ hybridization at the electron micrscopic level: Hybrid detection by autoradiography and colloidal gold. J. Cell Biol., 95, 609-618.

Jacob, J., Gillies, K., Macleod, D. and Jones, K., 1974. Molecular hydridization of mouse satellite DNAcomplementary RNA in ultrathin sections prepared for electron microscopy. J. Cell Sci., 14, 253-261. 
Jimenez-Garcia, L., Rothblum, L., Busch, H. and Ochs, R., 1989. Nucleologenesis: Use of non-isotopic in situ hybridization and immunocytochemistry to compare the localization of rDNA and nucleolar proteins during mitosis. Biology of the Cell, 65, 239-246.

John, H. A., Birnstiel, M. L. and Jones, K. W., 1969. RNA-DNA hybrids at the cytological level. Nature, 223, 582-587.

Johnson, E., Sterner, R. and Allfrey, V., 1987. Altered nucleosomes of active nucleolar chromatin contain accessible histone $\mathrm{H} 3$ in its hyperacetylated forms. J. biol. Chem., 262, 6943-6946.

Jordan, E. and Cullis, C., 1982. The nucleolus. In: Society for Experimental Biology, Seminar Series, Vol. 15, Cambridge University Press, Cambridge, London, New York, New Rochelle, Melbourne, Sydney.

Jordan, E. and Rawlins, D. J., 1990. Three-dimensional localization of DNA in the nucleolus of Spirogyra by correlated optical tomography and serial ultra-thin sectioning. J. Cell Sci., 95, 343-352.

Kellenberger, E., Durrenberger, M., Villiger, W., Carlemalm, E. and Wurtz, M., 1987. The efficiency of immunolabel on Lowicryl sections compared to theoretical predictions. J. Histochem. Cytochem., 35, 959-969.

Kim, R. A. and Wang, J. C., 1989. A subthreshold level of DNA topoisomerases leads to the excision of yeast rDNA as extrachromosomal rings. Cell, 57, 975-985.

Kornberg, R., 1977. Structure of chromatin. A. Rev. Biochem., 46, 931-954

Langer-Safer, P., Levine, M. and Ward, D., 1982. Immunological method for mapping genes on Drosophila polytene chromosomes. Proc. natn. Acad. Sci. U.S.A., 79, 4381-4385.

Lepoint, A., 1977. Selection of Ehrlich tumor cells in different phases of the cell cycle by ficoll gradient centrifugation. Virchows Archiv. B, 25, 53-60.

Martin, M., Moreno Diaz de la Espina, S. and Medina, F. J., 1989. Immunolocalization of DNA at nucleolar structural components in onion cells. Chromosoma, 98, 368-377.

McGhee, J. D. and Felsenfeld, G., 1980. Nucleosome structure. A. Rev. Biochem., 49, 1115-1156.

Miller, O., 1981. The nucleolus, chromosomes and visualization of genetic activity. J. Cell Biol., 91, 155-275.

Miller, O. and Beatty, B., 1969. Visualization of nucleolar genes. Science, 164, 955-957.

Moran, R., Darzynkiewicz, Z., Staiano-Coico, L. and Melamed, M., 1985. Detection of 5-bromodeoxyuridine (Brd Urd) incorporation by monoclonal antibodies: Role of the DNA denaturation step. J. Histochem. Cytochem., 33, 821-827.

Newman, G. R. and Hobot, J., 1987. Modern acrylics for post-embedding immunostaining techniques. J. Histochem. Cytochem., 35, 971-981.

Newman, G. R. and Jasani, B., 1984. Post-embedding immunoenzyme techniques. In: Immunolabelling for Electron Microscopy, Polak, J. M. and Vandell, I. M. (eds.), Elsevier, Amsterdam, New York, Oxford, 53-70.

Newman, G. R., Jasani, B. and Williams, E. D., 1982. The preservation of ultrastructure and antigenicity. J. Microsc. Oxford, 127, RP5-RP6.

Newman, G. R., Jasani, B. and Williams, E. D., 1983a. A simple postembedding system for the rapid demonstration of tissue antigens under the electron microscope. Histochem. J., 15, 543-555.
Newman, G. R., Jasani, B. and Williams, E. D., 1983b. Metal compound intensification of the electron density of diaminobenzidine. J. Histochem. Cytochem., 31, 1430-1434.

Notman, D. D., Kurata, N. and Tan, E. M., 1975. Profiles of antinuclear antibodies in systemic rheumatic diseases. Ann. intern. Med., 83, 464-469.

Ochs, R. L. and Smetana, K., 1989. Fibrillar center distribution in nucleoli of PHA-stimulated human lymphocytes. Expl Cell Res., 184, 552-557.

Polak, J. M. and Varndell, I. M. (eds.), 1984. Immunolabelling for Electron Microscopy, Elsevier, Amsterdam.

Priestley, J., 1984. Pre-embedding ultrastructural immunocytochemistry: Immunoenzyme techniques. In: Immunolabelling for Electron Microscopy, Polak, J. and Varndell, I. (eds.), Elsevier, Amsterdam, New York, Oxford, 37-52.

Prior, C., Cantor, C., Johnson, E., Littau, V. and Allfrey, V., 1983. Reversible changes in nucleosome structure and histone $\mathrm{H} 3$ accessibility in transcriptionally active and inactive states of rDNA chromatin. Cell, 34, 1037-1042.

Raap, A., Marijnen, J., Vrolijk, J. and van de Ploeg, M., 1986. Denaturation, renaturation and loss of DNA during in situ hybridization procedures. Cytometry, 7, 235-242.

Raska, I., Armbruster, B., Jira, M., Hana, I., Klaslik, J., Rovensky, J. and Smetana, K., 1983. Ultrastructural localization of DNA in tissue culture cell nucleoli by means of enzyme-gold and autoimmune sera-protein Agold techniques. Biology of the Cell, 48, 211-214.

Raska, I., Reimer, G., Jarnik, M., Kostrouch, Z. and Raska, K., 1989. Does the synthesis of ribosomal RNA take place within nucleolar fibrillar centers of dense fibrillar components? Biology of the Cell, 65, 79-82.

Rawlins, D. J. and Shaw, P. J., 1990. Three-dimensional organization of ribosomal DNA in interphase nuclei of Pisum sativum by in situ hybridization and optical tomography. Chromosoma, 99, 143-151.

Reeder, R., McKnight, S. and Miller, O., 1978. Contraction ratio of the nontranscribed spacer of Xenopus rDNA chromatin. Cold Spring Harb. Symp. quant. Biol., 42, $1174-1177$.

Reeves, R., 1984. Transcriptionally active chromatin. Biochim. biophys. Acta, 782, 343-393.

Reimer, G., Raska, I., Tan, E. and Scheer, U., 1987a. Human autoantibodies: probes for nucleolus structure and function. Virchows Archiv. B., 54, 131-143.

Reimer, G., Rose, K., Scheer, U. and Tan, E., 1987b. Autoantibody to RNA polymerase I in scleroderma sera. J. clin. Invest., 79, 65-72.

Rose, K. M., Stetler, D. A. and Jacob, S. T., 1981. Protein kinase activity of RNA polymerase I purified from a rat hepatoma: Probable function of $M_{\mathrm{r}} 42,000$ and 24,600 polypeptides. Proc. natn. Acad. Sci. U.S.A., 78, 2833-2837.

Rose, K. M., Stetler, D. A. and Jacob, S. T., 1983. RNA polymerases from higher eukaryotes. In: Enzymes of Nucleic Acid Synthesis and Modification, Jacob, S. T. (ed.), CRC Press, Inc., Boca Raton, Florida, 43-74.

Rose, K., Szopa, J., Han, F.-S., Cheng, Y.-C., Richter, A. and Scherr, U., 1988. Association of DNA topoisomerase I and RNA polymerase I: a posssible role for topoisomerase I in robosomal gene transcription. Chromsoma, 96, 411-416.

Roth, J., 1982a. The protein-A gold (pAg) technique-a qualitative and quantitative approach for antigen localization on thin sections. In: Techniques in Immunocytochemistry, Vol. 1, Bullock, G. R. and Petrusz, P. (eds.), Academic Press, London, 107-133. 
Roth, J., 1982b. The preparation of protein A-gold complexes with $3 \mathrm{~nm}$ and $15 \mathrm{~nm}$ gold particles and their use in labelling multiple antigens on ultra-thin sections. Histochem. J., 14, 791-801.

Roth, J., Bendayan, M., Carlemalm, E., Villiger, W. and Garavito, M., 1981. Enhancement of structural preservation and immunocytochemical staining in low temperature embedded pancreatic tissue. J. Histochem. Cytochem., 29, 663-671.

Scheer, U., 1987. Contributions of electron microscopic spreading preparations ("Miller spreads") to the analysis of chromosome structure. In: Structure and Function of Eukaryotic Chromosomes, Hennig, W., (ed.), SpringerVerlag, Berlin, 147-171.

Scheer, U. and Benavente, R., 1990. Functional and dynamic aspects of the Mammalian nucleolus. Bioassays, 12, 14-21.

Scheer, U., Messner, K., Hazan, R., Raska, I., Hansmann, P., Falk, H., Spiess, E. and Franke, W., 1987. High sensitivity immunolocalization of double- and single-stranded DNA by a monoclonal antibody. Eur. J. Cell Biol., 43, 358-371.

Scheer, U. and Raska, I., 1987. Immunocytochemical localization of RNA polymerase I in the fibrillar centers of nucleoli. In: Chromosomes Today, Vol. 9, Stahl, A., Luciani, J. and Wagner-Capodano, A. (eds.), Allen and Unwin, London, 284-294.

Scheer, U. and Rose, K., 1984. Localization of RNA polymerase I in interphase cells and mitotic chromsomes by light and electron microscopic immunocytochemistry. Proc. natn. Acad. Sci. U.S.A., 81, 1431-1435.

Schmidt-Zachmann, M., Hügle, B., Scheer, U. and Franke, W., 1984. Identification and localization of a novel nucleolar protein of high molecular weight by a monoclonal antibody. Expl Cell Res., 153, 327-346.

Slot, J. and Geuze, H., 1981. Sizing of protein A-colloidal gold probes for immunoelectron microscopy. J. Cell Biol., 90, 533-536.

Slot, J. and Geuze, H., 1985. A new method of preparing gold probes for multiple-labeling cytochemistry. Eur. J. Cell Biol., 38, 87-93.

Smetana, K. and Busch, H., 1974. The nucleolus and nucleolar DNA. In: The Cell Nucleus, Vol. 1, Busch, H. (ed.), Academic Press, New York, 73-147.

Stierhof, Y.-D. and Schwarz, H., 1988. Immunoelectronmicroscopy on cryosections section permeability to specific antibodies, protein A-gold complexes and ferritin conjugated IgGs. Institute of Physics Conference Series Number 93, Eurem 88, Vol. 3: Biology, 519-520.

Stollar, B. D., 1975. The specificity and applications of antibodies to medical nucleic acids. CRC Crit. Rev. Biochem., 3, 45-69.

Stollar, B., Zon, G. and Pastor, R., 1986. A recognition site on synthetic helical oligonucleotides for monoclonal anti-native DNA autoantibody. Proc. natn. Acad. Sci. U.S.A., 83, 4469-4473.

Tan, E. M., 1982. Autoantibodies to nuclear antigens (ANA): their immunobiology and medicine. Adv. Immun., 33, 167-240.

Tan, E., Chan, E., Sullivan, K. and Rubin, R., 1988. Antinuclear antibodies (ANAs): diagnostically specific immune markers and clues toward the understanding of systemic autoimmunity. Clin. Immunol. Immunopath., 47, 121-141.

Thiry, M., 1988. Immunoelectron microscope localization of bromodeoxyuridine incorporated into DNA of Ehrlich tumor cell nucleoli. Expl Cell Res., 179, 204-213.
Thiry, M., 1989. Organisation ultrastructurale du nucléole au cours du cycle cellulaire. Etude cytochimique, immunocytochimique et par hybridation in situ. Thesis, University of Liège, 1-158.

Thiry, M. and Dombrowicz, D., 1988. Anti-bromodeoxyuridine monoclonal antibody: alternative tool for the identification of replicated DNA at the electron microscope level. Biology of the Cell, 62, 99-102.

Thiry, M., Lepoint, A. and Goessens, G., 1985. Re-evaluation of the site of transcription in Ehrlich tumour cell nucleoli. Biology of the Cell, 54, 57-64.

Thiry, M. and Muller, S., 1989. Ultrastructural distribution of histones within Ehrlich tumor cell nucleoli. A cytochemical and immunocytochemical study. J. Histochem. Cytochem. 37, 853-862.

Thiry, M., Scheer, U. and Goessens, G., 1988. Localization of DNA within Ehrlich tumour cell nucleoli by immunoelectron microscopy. Biology of the Cell, 63, 27-34.

Thiry, M. and Thiry-Blaise, L., 1989. In situ hybridization at the electron microscope level: an improved method for precise localization of ribosomal DNA and RNA. Eur. J. Cell Biol., 50, 235-243.

Tischendorf, G. and Kapfer, W., 1988. Electron microscopic studies of antibody-gold complexes as prepared by a solidphase technique. Institute of Physics Conference Series Number 93, Eurem 88, Vol. 3: 433-444.

Tokuyasu, K. T., 1978. A study of positive staining of ultrathin frozen sections. J. Ultrastruct. Res., 63, 287-307.

Tokuyasu, K. T., 1980. Immunochemistry on ultrathin frozen sections. Histochem. J., 12, 381-403.

Tokuyasu, K. T., 1984. Immuno-cryoultramicrotomy. In: Immunolabelling for Electron Microscopy, Polak, J. and Varndell, I. (eds.), Elsevier Science, Amsterdam, New York, Oxford, 71-82.

Tokuyasu, K. T., 1986. Application of cryoultramicrotomy to immunocytochemistry. J. Microsc. Oxford, 143, 139-149.

Trendelenburg, M., 1983. Progress in visualization of Eukaryotic gene transcription. Human Genetics, 63, 197-215.

Van Holde, K. E., 1989. Chromatin, Springer-Verlag, New York.

Wachtler, F., Hartung, M., Devictor, M., Wiegant, J., Stahl, A. and Schwarzacher, H., 1989. Ribosomal DNA is located and transcribed in the dense fibrillar component of human Sertoli cell nucleoli. Expl Cell Res., 184, 61-71.

Wachtler, F., Hopman, A., Wiegant, J. and Schwarzacher, H., 1986. On the position of nucleolus organizer regions (NORs) in interphase nuclei. Studies with a new, nonautoradiographic in situ hybridization method. Expl Cell Res., 167, 227-240.

Wang, J., 1985. DNA topoisomerases. A. Rev. Biochem., 54, 665-697.

Williams, M., 1977. Quantitative methods in biology. In: Practical Methods in Electron Microscopy, Vol. 6, Glauert, A. (ed.), North-Holland, American, Elsevier, 1-216.

Yokota, S., 1988. Effect of particle size on labeling density for catalase in protein A-gold immunocytochemistry. J. Histochem. Cytochem., 36, 107-109.

Zayetz, V., Bavykin, S., Karpov, V. and Mirzabekov, A., 1981. Stability of the primary organization of nucleosome core particles upon some conformational transitions. Nucl. Acids Res., 9, 1053-1068.

Zhang, H., Wang, J. and Liu, L., 1988. Involvement of DNA topoisomerase I in transcription of human ribosomal RNA genes. Proc. natn. Acad. Sci. U.S.A., 85, 1060-1064. 